\title{
Chronione, rzadkie i zagrożone gatunki roślin naczyniowych we florze Wzgórz Chęcińskich i Pasma Dymińskiego (Wyżyna Małopolska) - cz. II. Gatunki leśne i zaroślowe
}

\author{
GRZEGORZ ŁAZARSKI
}

\begin{abstract}
ŁAZARSKI, G. 2020. Protected, rare and endangered vascular plant species in the Chęciny Hills and Dyminy Range (Małopolska Upland) - part II. Forest and shrubland species. Fragmenta Floristica et Geobotanica Polonica 27(2): 423-450. Kraków. e-ISSN 2449-8890, ISSN 1640-629X.
\end{abstract}

\begin{abstract}
This is the second part of a series of papers on protected, rare and threatened vascular plant species recorded in the Chęciny Hills and Dyminy Range (Małopolska Upland, S Poland), including 106 native species from forest and shrub communities. Among them are 43 species protected in Poland, 37 species red-listed in Poland, and 75 species from the red list of the Małopolska Upland. The paper is based on phytogeographical studies done during the vegetative seasons of 2010-2015, supplemented in 2016-2019.
\end{abstract}

KEY WORDS: new localities, Świętokrzyskie Mountains, thermophilous species, threatened species

G. Lazarski, Uniwersytet Przyrodniczo-Humanistyczny w Siedlcach, Wydział Nauk Ścistych i Przyrodniczych, ul. Prusa 14,08-110 Siedlce,Polska; e-mail: grzegorz.lazarski@gmail.com

\section{WSTĘP}

Wzgórza Chęcińskie i Pasmo Dymińskie zajmują południowo-zachodnią część Gór Świętokrzyskich (KONDRACKI 2002). Badany teren charakteryzuje się urozmaiconą rzeźbą i bogactwem siedlisk, co przekłada się na wysoką różnorodność flory i roślinności. Flora tej części Gór Świętokrzyskich odznacza się dużym udziałem gatunków ciepłolubnych, które związane są zarówno z nieleśnymi, jak i leśnymi siedliskami wykształconymi na wapiennych wzniesieniach. Stan poznania flory badanego terenu, jego charakterystykę wraz ze szczegółową mapą topograficzną zawarto w części pierwszej opracowania (ŁAZARSKI 2019). Położenie Wzgórz Chęcińskich i Pasma Dymińskiego w sieci ATPOL przedstawia rycina 1. W niniejszej pracy wymieniono stanowiska chronionych, rzadkich i zagrożonych gatunków, które zostały stwierdzone w zbiorowiskach leśnych i zaroślowych.

Spośród zbiorowisk leśnych południowo-zachodniej części Gór Świętokrzyskich największe powierzchnie zajmują bory mieszane (Querco roboris-Pinetum). Część z nich to przekształcone w wyniku pinetyzacji grądy i świetliste dąbrowy. U podnóży wzniesień i w piaszczystych dolinach między nimi wykształciły się głównie świeże bory kontynentalne (Peucedano-Pinetum). W obniżeniach terenu w kompleksach lasów iglastych występują 
bory bagienne (Vaccinio uliginosi-Pinetum) oraz wilgotne (Molinio-Pinetum), których płaty tworzą mozaikowy układ. W obrębie Pasma Dymińskiego i Pasma Posłowickiego obserwowano płaty wyżynnego jodłowego boru mieszanego (Abietetum polonicum) o ubogim składzie florystycznym. Bez wątpienia najcenniejszymi przyrodniczo zbiorowiskami leśnymi badanej części Gór Świętokrzyskich są bogate florystycznie świetliste dąbrowy (Potentillo albae-Quercetum). Lasy te porastają południowe, południowo-zachodnie i zachodnie zbocza oraz szczytowe partie wapiennych wzniesień, głównie Wzgórz Chęcińskich. Obecnie świetliste dąbrowy są $\mathrm{w}$ recesji $\mathrm{w}$ następstwie zaniechania tradycyjnego ich użytkowania oraz niewłaściwej gospodarki leśnej. Na mniej nasłonecznionych zboczach wzniesień występują grądy subkontynentalne (Tilio-Carpinetum) (PRZEMYsKi \& Solon 2010). W mikroregionie Pasma Dymińskiego grądom towarzyszą niewielkie płaty żyznych buczyn z Dentaria enneaphyllos i D. bulbifera (spotykane w mocno zacienionych, głębokich wąwozach, jak i na zboczach o największym nachyleniu). PrzemYSKi i SoLON (2010) zwrócili uwagę na występowanie w obrębie Pasma Zgórskiego zbiorowiska leśnego, które składem florystycznym nawiązuje do buczyn storczykowych. Obficie występują tutaj przedstawiciele storczykowatych z rodzajów Cephalanthera, Platanthera, Epipactis, którym towarzyszą gatunki ciepłolubne. Autorzy wskazują, że jednoznaczne określenie pozycji syntaksonomicznej tego zbiorowiska wymaga szczegółowych badań fitosocjologicznych. W dolinach rzek i cieków wodnych występują głównie łęgi olszowo-jesionowe (Fraxino-Alnetum) oraz niewielkie powierzchnie wiklinowisk nadrzecznych (Salicetum triandro-viminalis). W bezodpływowych zagłębieniach terenu i w dolinach rzecznych spotykano płaty olsów porzeczkowych (Ribeso nigri-Alnetum) (PRZEMYSKI \& SOLON 2010). Zbiorowiska ciepłolubnych

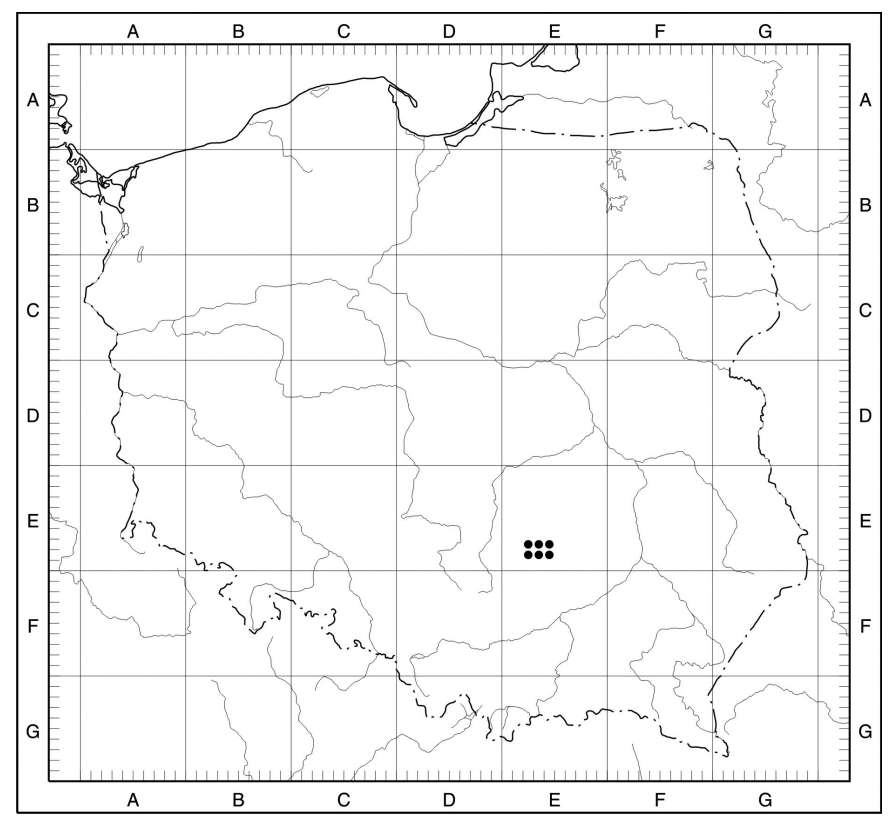

Ryc. 1. Położenie Wzgórz Chęcińskich i Pasma Dymińskiego w sieci ATPOL

Fig. 1. Location of the Chęciny Hills and Dyminy Range in the ATPOL grid square system 
zarośli z klasy Rhamno-Prunetea zajmują duże powierzchnie zwłaszcza w obrębie Wzgórz Chęcińskich. Reprezentowane są one przede wszystkim przez zespół Pruno-Ligustretum oraz Rhamno-Cornetum sanguinei. Na skutek zaprzestania działalności pasterskiej areał tych fitocenoz na bezleśnych wapiennych wzgórzach powiększa się kosztem bogatych florystycznie muraw kserotermicznych z klasy Festuco-Brometea i okrajków ciepłolubnych z klasy Trifolio-Geranietea sanguinei. Pośród zwykle ubogich florystycznie ciepłolubnych zarośli występuje rzadkie w kraju zbiorowisko z wiśnią karłowatą Cerasus fruticosa ze związku Prunion fruticosae (GŁAZEK 1987; MAtuszkiewicz 2008). Wykształca się ono w szczytowych partiach odlesionych wapiennych wzniesień, często w sąsiedztwie miejsc, gdzie w przeszłości lokalnie eksploatowano skały wapienne.

Celem tej pracy jest przedstawienie aktualnych stanowisk oraz częstości występowania chronionych, rzadkich i zagrożonych gatunków roślin naczyniowych Wzgórz Chęcińskich i Pasma Dymińskiego stwierdzonych w zbiorowiskach leśnych i zaroślowych.

\section{METODYKA}

Badania fitogeograficzne w południowo-zachodniej części Gór Świętokrzyskich prowadzono w latach 2010-2015 (uzupełnień dokonano w latach 2016-2019) zgodnie z metodyką opisaną w pierwszej części pracy (ŁAZARSKI 2019).

Nazwy taksonów podano zgodnie z MiRKIEM i in. (2002) w porządku alfabetycznym. Lista obejmuje stwierdzone w zbiorowiskach leśnych i zaroślowych gatunki rzadkie oraz wykazane w Polskiej czerwonej księdze roślin (KAŹMIERCZAKOwA i in. 2014), polskiej „,czerwonej liście” (KAŹMIERCZAKOwA i in. 2016), „czerwonej liście” Wyżyny Małopolskiej (Bróż \& PRZEMYSKI 2009) lub podlegające ochronie w Polsce (ROZPORZĄDZENIE 2014). Dany gatunek uznawano za leśny lub zaroślowy, kiedy większość jego stanowisk stwierdzono w zbiorowiskach leśnych lub zaroślowych. Listę uzupełniono o gatunki górskie (ZAJĄC 1996) oraz gatunki, które na badanym terenie posiadały nie więcej niż 9 stanowisk (tj. w zastosowanej skali częstości zostały zaklasyfikowane jako „rzadkie” lub „bardzo rzadkie”). Dla każdego gatunku podano liczbę oraz numery kwadratów ATPOL o boku 2,5 km, w których był notowany (dwie pierwsze cyfry oznaczają numer kwadratu o boku $10 \mathrm{~km}$, dwie kolejne - numer kwadratu o boku 2,5 km). Wszystkie pola badawcze położone są w kwadracie EE (o boku $100 \mathrm{~km}$ ), dlatego przy opisie stanowisk pominięto ten literowy symbol (ZAJAC 1978).

Zastosowane skróty i symbole: CH - gatunek objęty ochroną ścisłą; ch - gatunek objęty ochroną częściową; gat. górski - gatunek górski (ogólnogr. - gatunek ogólnogórski, podgr. - gatunek podgórski, regl. - gatunek reglowy); zagr./zagr. r. - gatunek zagrożony w kraju/gatunek zagrożony w regionie (kategorie z ,czerwonej księgi” podkreślono; kategorie: CR - krytycznie zagrożony; EN - zagrożony; VU - narażony; NT - bliski zagrożenia; LC - najniższego zagrożenia; DD - brak dostatecznych danych); ! - nowy gatunek (lub stanowisko) dla terenu badań; dol. - dolina; g. - góra; gm. - gmina; k. - koło; kośc. - kościół; kr. - kraniec; msc. - miejscowość; Not. - notowany; obr. - obręb leśny; oddz. - oddział leśny; P. - Pasmo; podn. - podnóże; prz. - przysiółek; rz. - rzeka; st. kol. - stacja kolejowa; stan. - stanowisko; w. - wieś; Wzg. - Wzgórza/wzgórze.

\section{WYKAZ GATUNKÓW}

Aconitum variegatum subsp. variegatum - Łęgi, zarośla łęgowe w dolinach rzek, grądy; ch; zagr. r.: VU; gat. górski (regl.).

14 stan.: !7223 - na S od W kr. w. Rykoszyn; !7230 - na SW od w. Kopaniny; 7233 - na S od prz. Charężów, dol. Hutki; 7323 - Kielce - Dobromyśl, dol. Bobrzy; 7332 - na NE od msc. Czerwona G., E podn. g. Malik, w dol. Bobrzyczki; !8202 - na N od w. Jedlnica, dol. Hutki; 8212 - na S od w. Jedlnica, 
dol. Hutki (ŁAZARSKI 2011); !8213 - na N od w. Mosty, Grzywy Korzeckowskie; 8302 - na W od w. Bolechowice; na E od msc. Czerwona G., E podn. g. Malik, w dol. Bobrzyczki; !8312 - na SW od prz. Podmoszcze; na N od SE kr. w. Radkowice; !8320 - na SE od SE kr. w. Mosty; 8412 - na N od w. Bilcza - Zastawie, dol. Chodczy; !8413 - na E od S kr. w. Suków - Modrzewie, dol. Lubrzanki; na NW od NW kr. w. Marzysz, dol. Lubrzanki; !8422 - na SE od w. Bilcza - Zastawie, dol. Chodcza; na NE od E kr. w. Bieleckie Młyny, dol. Czarna Nida.

Not.: u podn. G. Foltańskiego k. Słowika, leg. Bróż \& Molendowski 1985 (KTC); MasSALSKI 1962; BRóż 1981b; Bróż \& PrZEMYSKI 1983-1985a, 1987, 1988, 1989; Bróż i in. 1990.

Adenophora liliifolia - Świetliste dąbrowy (też postacie zdegenerowane tego zbiorowiska); $\mathrm{CH}$; zagr: $\underline{\mathrm{CR}}, \mathrm{CR}$; zagr. r.: EN.

4 stan.: wykaz stanowisk w pracy ŁAZARSKI (2017).

Not.: wzg. wapienne pod Bocheńcem, k. Małogoszcza, leg. Kaznowski 1925 (KRAM); P. Korzeckowskie, Jedlnica, leg. Kaznowski 1927 (KRAM); Grzywy Korzeckowskie, N część, leg. Rajkowska 1978 (KTC); G. Stokowa, leg. Bróż 1975 (KTC); W zbocze G. Foltańskiego, k. Słowika, leg. Bróż \& Molendowski 1985 (KTC); Bróż \& DurCZAK 1978; Bróż 1981b; Bróż \& PrZEMYsKi 1988; BRóż i in. 1990.

! Allium ursinum subsp. ucrainicum - Wąwozy w grądach i buczynach; ch; zagr. r.: NT; gat. górski (ogólnogr.).

2 stan.: !7333 - na S od msc. Kielce - Białogon; !7430 - na N od W kr. ul. Posłowickiej, Kielce.

Not.: (dane dla Allium ursinum s. lato) KAZNOwsKi 1922; Bróż i in. 1990; Rola 2012.

Anemone ranunculoides - Łęgowe zarośla nadrzeczne, grądy; zagr. r.: LC.

9 stan.: !7230 - na NE od w. Zakrucze, dol. Wiernej Rz.; 7332 - na NW od msc. Zgórsko, N zbocze g. Patrol; !7333 - na E od st. kol. Słowik; !7430 -a na N od W kr. ul. Posłowickiej, Kielce; !8201 - na N od w. Milechowy (Grząby Bolmińskie); !8211 - na E od w. Bocheniec; 8212 - Papiernia k. w. Bolmin; !8302 - Czerwona G., N i E zbocze; !8320 - na SE od SE kr. w. Mosty.

Not.: BRóż i in. 1990.

Antennaria dioica - Świeże bory sosnowe; zagr.: NT; zagr. r.: NT.

2 stan.: !7230 - na E od w. Zakrucze, Bolmińska G., W podn.; !8200 - na NE od w. Dołki, g. Brogowica. Not.: BRÓż i in. 1990.

! Anthriscus nitida - Olsy, łęgi; zagr. r.: VU; gat. górski (regl.). 2 stan.: !7230 - na SW od w. Kopaniny (dol. Wiernej Rz.); !8412 - na N od w. Bilcza - Zastawie, dol. Chodczy.

Aquilegia vulgaris - Świetliste dąbrowy, bory mieszane;

ch. 29 stan.: !7222 - na N od w. Lesica; 7230 - na E od w. Zakrucze, Bolmińska G.; 7231 - na N od w. Milechowy; !7233 - na S od W kr. w. Gałęzice; !7321 - Jaworznia, g. Moczydła; 7322 - na N od w. Janów, Podzamecka G.; 7323 - Kielce - Białogon, g. Brusznia; 77330 - na SE od E kr. w. Gałęzice, G. Żakowa; 7332 - na NW od msc. Zgórsko; 7333 - na E od st. kol. Słowik; !7431 - na N od ul. Leśniówka, Kielce; 7432 - na NW od W kr. w. Suków - Borki; 8200 - na N od w. Dołki, g. Brogowica; 8201 Milechowy k. wsi Bolmin; !8203 - Polichno; 8211 - na N od wsi Bocheniec; !8212 - na S od w. Bolmin, Wzg. Wilkomijskie; 8213 - na S od w. Korzecko - Zarośle, Grzywy Korzeckowskie; !8223 - na S od w. Mosty, g. Bzowica; 8302 - N zbocze Czerwonej G.; !8303 - Nowiny, gm. Sitkówka - Nowiny; !8310 - na S od E kr. w. Korzecko, Grzywy Korzeckowskie; !8400 - na S od ul. Na Stole, Kielce, Kowalski Las; 8401 - na S od ul. Leśniówka, Kielce, Kowalski Las; !8402 - na S od W kr. w. Suków - Babie, N zbocze Babiej G.; ! 8411 - na N od w. Bilcza - Podgórze, Kowalski Las; 8412 - na S od W kr. w. Suków - Babie, S zbocze Babiej G.; !8413 - na S od S kr. w. Suków - Modrzewie; !8422 - na NW od W kr. w. Kuby - Młyny.

Not.: Drymmer 1890; Bróż \& DurCZaK 1978; Bróż \& PRZemyski 1981; WNuK 1986.

Arctostaphylos uva-ursi - Świeży bór sosnowy; CH; zagr.: NT; zagr. r.: NT. 1 stan.: !8413 - na SW od S kr. w. Suków - Modrzewie.

Not.: Browicz \& KaCZMAReK 1972; Bróż 1981b. 
Aruncus sylvestris - Grądy, łęgi; ch; zagr. r.: NT; gat. górski (regl.). 10 stan.: !7233 - na NW od W kr. w. Skiby; 7332 - na NW od msc. Zgórsko; 7333 - na E od st. kol. Słowik; !7430 - na N od W kr. ul. Posłowickiej, Kielce; !7431 - na S od msc. Kielce - Kawetczyzna; !7432 - na NW od W kr. w. Suków - Borki; !7433 - Mójcza, dol. Lubrzanki; !8213 - na N od w. Mosty, Grzywy Korzeckowskie; 8310 - na S od E kr. w. Korzecko, Grzywy Korzeckowskie; !8412 - na N od w. Bilcza - Zastawie, dol. Chodczy.

Not.: Massalski 1962; BRÓż \& PrZemyski 1987; Bróż i in. 1990.

Astragalus arenarius - Bory sosnowe, murawy na piaskach; zagr.: NT. 18 stan.: !7323 - Kielce - Białogon, S podn. g. Marmurek; 7433 - Mójcza; !8202 - na N od w. Jedlnica, Grząby Bolmińskie; !8203 - na NE od w. Jedlnica, g. Chrostynka; !8212 - na S od w. Bolmin; 8312 - na N od w. Radkowice; !8320 - na SE od SE kr. w. Mosty; !8322 - na S od w. Lipowica; !8323 - na SW od W kr. w. Brzeziny, Las Nidzki; !8401 - na S od ul. Leśniówka, Kielce, Kowalski Las; !8402 - na S od E kr. msc. Kielce - Dyminy; !8411 - na N od w. Bilcza - Podgórze, Kowalski Las; !8412 - na N od w. Bilcza - Zastawie; !8413 - na S od S kr. w. Suków - Modrzewie; 8420 - centr. cz. w. Brzeziny; !8421 - Piaseczna Górka; !8422 - Bilcza - Zastawie; !8423 - Marzysz - Młyny.

Not.: DRYMMER 1890; BRÓż i in. 1990.

Avenula planiculmis var. hispidula - Bory mieszane, świetliste dąbrowy; zagr.: VU; VU; zagr. r.: VU. 6 stan.: 7230 - na E od w. Zakrucze, W zbocze g. Brodowej; 8200 - na N od w. Dołki, E zbocze g. Brogowica (ŁAZARSKI 2012); 8201 - na W od W kr. w. Bolmin, N kraniec pasma z Bocheńską G.; 8211 - na NW od ośrodka wypoczynkowego we w. Bocheniec, Bocheńska G., N i S zbocze (ŁAZARSKI 2011; 2012; FreY i in. 2014); 8212 - na W od w. Choiny, przy ujściu Wiernej Rz., Wzg. Wilkomijskie (ŁAZARSKI 2012); na E od msc. Nowa Wieś k. Bocheńca, skarpa doliny Białej Nidy; 8213 - na N od NW kr. w. Mosty, S podn. Grzyw Korzeckowskich.

Not.: Grzywy Korzeckowskie, k. w. Korzecko, oddz. 188, leg. Bróż 1977 (KTC); g. Brogowica, leg. Bróż \& Walas 1978 (KTC); G. Milechowska, k. w. Milechowy, leg. Bróż \& Łanocha 1978 (KTC); Wzgórza Wilkomijskie k. w. Choiny, leg. Bróż \& Przemyski 1981 (KTC); Bocheńska G., leg. Bróż 1982 (KTC); BRÓż 1981b; 1986; BRóż \& PrZEMYski 1983-1985b, 1988, 1989; Frey 1991; PodSIEdLIK \& BedNORZ 2012.

! Barbarea stricta - Skraje zarośli łęgowych w dolinach rzek; zagr. r.: CR. 4 stan.: 7230 - na E od w. Zakrucze, dol. Wiernej Rz.; 8200 - SE od w. Zakrucze, dol. Wiernej Rz.; 8211 - na NW od wsi Bocheniec, dol. Wiernej Rz.; 8212 - na W od NW kr. W. Mosty, dol. Hutki.

! Bromus benekenii - Grądy; zagr. r.: VU. 5 stan.: 7230 - na E od w. Zakrucze, g. Brodowa; 7231 - na W od osady Gajówka, na SW od G. Milechowskiej; 8300 - na N od w. Skiby, G. Wsiowa; 8302 - E zbocze Czerwonej G; 8320 - na SE od E kr. w. Mosty.

Bupleurum longifolium - Grądy, zbiorowiska przejściowe między grądami a świetlistymi dąbrowami; CH; zagr.: EN; zagr. r.: VU; gat. górski (ogólnogr.). 7 stan.: 7221 - na E od w. Wesoła, N zbocze Wesołowskiej G.; !7230 - na NW od w. Milechowy, m. Brodową a Milechowską G.; 7231 - na NW od osady Gajówka, N zbocze Milechowskiej G.; 7323 - Kielce - Białogon, G. Stokowa; NW zbocze g. Bruszni; 8211 - na N od ośrodka wypoczynkowego we w. Bocheniec, Bocheńska G., N zbocze (ŁAZARSKI 2011); 8212 - na SE od ujścia Wiernej Rz., Wzg. Wilkomijskie (ŁAZARSKI 2011); 8213 - na S od w. Korzecko - Zarośle, Grzywy Korzeckowskie.

Not.: G. Milechowska, leg. Bróż \& Łanocha 1978 (KTC); Grzywy Korzeckowskie, g. Grzywy, leg. Bróż 1982 (KTC); P. Kadzielniańskie, Stokowa G., Kielce-Białogon, leg. Bróż 1984 (KTC); KAZnowSKI 1922; Massalski 1962; Bróż \& DurCZaK 1978; Bróż 1981a; Bróż \& PrZemyski 1988.

Calamagrostis villosa - Jedliny, bory bagienne, podtorfione łąki. Gat. górski (ogólnogr.). 5 stan.: !7322 - na N od w. Janów; 7432 - na N od msc. Kielce - Pod Telegrafem, N zbocze g. Telegraf; na S od msc. Kielce - Bukówka; !7433 - Mójcza; !8402 - na NE od E kr. msc. Kielce - Dyminy; !8412 - na S od W kr. w. Suków - Babie; na NE od osady Podsukowie.

Not.: BRóż i in. 1990. 
Campanula cervicaria - Bór mieszany, świetlista dąbrowa; zagr.: DD; DD. 2 stan.: !8200 - na N od w. Dołki, g. Brogowica; !8211 - na NE od wsi Bocheniec, Bocheńska G.

Not.: BRÓż i in. 1990.

! Cardamine flexuosa - Wilgotne pobocza dróg w grądach i buczynach; zagr. r.: VU. 3 stan.: 7332 - na N od msc. Zgórsko; 7333 - na NE od msc. Słowik, na S od g. Biesak; 7430 - na N od W kr. ul. Posłowickiej, Kielce.

! Cardamine impatiens - W grądzie przy wychodni skał wapiennych, zarośla łęgowe; zagr. r.: VU. 3 stan.: 7330 - na NW od w. Skiby, G. Żakowa; 7332 - na NE od msc. Czerwona G., dol. Bobrzyczki; 8302 - na E od msc. Czerwona G., dol. Bobrzyczki.

! Carex pallidula - Świetliste dąbrowy, murawy kserotermiczne, ciepłolubne zarośla i okrajki; zagr.: NT; NT; zagr. r.: CR. 12 stan.: 7221 - Wesoła, S zbocze G. Wesołowskiej; 7230 - na NW od w. Milechowy, g. Brodowa; 7322 - na N od E kr. w. Jaworznia, g. Kopaczowa; 7323 - na NE od msc. Kielce-Białogon (G. Stokowa; g. Brusznia); 8202 - na NW od w. Jedlnica, Grząby Bolmińskie; g. Chrusznica; 8203 - Polichno, podn. g. Żebrowicy; 8211 - na NE od w. Bocheniec, Bocheńska G. (ŁAZARSKI i in. 2014); 8213 - na N od W kr. w. Mosty, Grzywy Korzeckowskie; 8300 - na NE od w. Skiby, S zbocze g. Zelejowa; 8302 - NW zbocze Czerwonej G.; 8310 - na N od w. Korzecko, g. Rzepka; 8400 - na N od w. Kowala.

Cephalanthera damasonium - Świetliste dąbrowy, grądy, bory mieszane, zarośla ciepłolubne; $\mathrm{CH}$; zagr.: NT; zagr. r.: VU. 23 stan.: 7221 - na E od w. Wesoła, Wesołowska G.; !7230 - na E od w. Zakrucze, Bolmińska G.; 7231 - na NW od w. Milechowy, m. Brodową a Milechowską G.; !7330 - na SE od E kr. w. Gałęzice, G. Żakowa; 7331 - na S od w. Szewce, g. Okrąglica; 7332 - na NW od msc. Zgórsko; 8200 - na NW od w. Dołki, g. Brogowica; 8201 - Milechowy k. wsi Bolmin, na W od wsi Milechowy; 8202 - na N od E kr. w. Bolmin, Grząby Bolmińskie; 8211 - na N od wsi Bocheniec; !8212 - na S od w. Bolmin, Wzg. Wilkomijskie (ŁAZARSKI 2011); !8213 - na S od w. Korzecko - Zarośle, Grzywy Korzeckowskie; 8300 - na N od w. Skiby, G. Wsiowa; 8301 - Zelejowa; 8302 - Bolechowice; 8310 - na S od E kr. w. Korzecko, Grzywy Korzeckowskie; 8311 - na SW od msc. Chęciny, g. Rzepka; !8320 - Tokarnia, las na terenie skansenu; !8323 - na SW od W kr. w. Brzeziny, Las Nidzki; !8401 - na S od ul. Leśniówka, Kielce, Kowalski Las; 8410 - na S od w. Kowala Mała, Kowalska G.; !8411 - na N i S od w. Bilcza - Podgórze; !8422 - na NW od W kr. w. Kuby - Młyny.

Not.: Massalski 1962; Bróż i in. 1990; CioseK \& Bzdon 2000.

Cephalanthera longifolia - Dąbrowy, grądy, buczyny storczykowe; CH; zagr.: VU; zagr. r.: VU. 11 stan.: !7320 - na SW od W kr. w. Łaziska k. Piekoszowa; !7321 - na S od W kr. w. Jaworznia; !7322 - na S od E kr. w. Jaworznia; 7331 - Szewce; 7332 - na NW od msc. Zgórsko; 7333 - na E od st. kol. Słowik; 7430 - na N od W kr. ul. Posłowickiej, Kielce; 7431 - na S od msc. Kielce - Kawetczyzna; !8313 - na W od W kr. w. Brzeziny; !8323 - na SW od W kr. w. Brzeziny, Las Nidzki; !8402 - na NE od E kr. msc. Kielce - Dyminy.

Not.: BRÓż 1981b; BRóż i in. 1990.

Cephalanthera rubra - Grądy, świetliste dąbrowy, bór mieszany; CH; zagr.: VU; VU; zagr. r.: EN. 6 stan.: 7231 - na NW od w. Milechowy, m. Brodową a Milechowską G.; 8201 - Milechowy k. wsi Bolmin, na N od E krańca wsi Milechowy; !8212 - na SE od ujścia Wiernej Rz., Wzg. Wilkomijskie (ŁAZARSKI 2011); 8213 - na S od w. Korzecko - Zarośle, Grzywy Korzeckowskie; 8310 - na S od E kr. w. Korzecko, Grzywy Korzeckowskie; !8320 - na E od SE kr. w. Mosty, S podn. g. Moskozala.

Not.: Bróż 1981a; Bróż \& Przemyski 1988; Ciosek \& Bzdon 2000; Przemyski \& Piwowarski 2011.

Cerasus fruticosa - Ciepłolubne zarośla; ch; zagr.: VU; VU; zagr. r.: VU. 14 stan.: !7221 - na E od w. Wesoła, Wesołowska G.; !7230 - na E od w. Zakrucze, Bolmińska G.; !8202 - na N od E kr. w. Bolmin, Grząby Bolmińskie; !8203 - Polichno - pasmo na S od wsi; g. Chrostynka; g. Hutka; na S od w. Stawki, Laskowa G.; 8211 - na N od wsi Bocheniec; 8300 - na NE od msc. Chęciny - Zatropie; na S od E kr. w. Gościniec, S i SE zbocze g. Zegzela; 8301 - na N od msc. Chęciny, g. Zelejowa; 8310 - na E od msc. 
Chęciny - Zatropie; na S od E kr. w. Korzecko, Grzywy Korzeckowskie; 8311 - na S od msc. Chęciny; na N od w. Starochęciny, Zaklikowa G.; !8312 - na N od w. Radkowice; !8321 - na NE od w. Tokarnia; na N od W kr. w. Przymiarki; !8322 - na W od w. Lipowica, g. Grabówki; !8323 - na S od W kr. w. Brzeziny; !8411 - na S od w. Bilcza.

Not.: MAsSALSKi 1962; Browicz \& GostyŃsKa 1964; MAZUR 1975; GŁAZEK 1976a; Bróż \& DuRCZAK 1978; BRÓŻ 1986; BRÓż \& MACIEJCZAK 1991.

Chaerophyllum hirsutum - Cieniste wąwozy w grądach, olsy, brzegi strumieni. Gat. górski (ogólnogr.). 9 stan.: !7230 - na NE od w. Zakrucze, dol. Wiernej Rz.; !7333 - Kielce - Białogon, N podn. g. Biesak; 7430 - na N od msc. Posłowice; 7431 - na S od msc. Kielce - Kawetczyzna; !8202 - na N od w. Jedlnica; !8401 - na S od W kr. msc. Kielce - Dyminy; 8412 - na N od w. Bilcza - Zastawie, dol. Chodczy; !8421 - na NW od w. Piaseczna Górka; !8422 - Bilcza - Zastawie.

Not.: BRÓż \& PRZEMYSKI 1981; BRÓŻ i in. 1990.

Chimaphila umbellata - Bory sosnowe; ch; zagr.: NT; zagr. r.: NT. 35 stan.: !7222 - na N od w. Bławatków; !7223 - W kr. w. Rykoszyn; 7230 - na E od w. Zakrucze; 7231 - na N od w. Milechowy; !7232 - Miedzianka; !7233 - na N od w. Polichno; !7312 - Szczukowice; !7320 - na SW od W kr. w. Łaziska k. Piekoszowa; !7321 - na S od W kr. w. Jaworznia; 7323 - na N od msc. Kielce - Białogon; !7330 - na E od E kr. w. Gałęzice; !7331 - na S od E kr. w. Zawada; 7333 - Słowik - Markowizna; !7430 - na N od W kr. ul. Posłowickiej, Kielce; 7431 - na N od ul. Leśniówka, Kielce; 7432 - na S od msc. Kielce - Pod Telegrafem; !7433 - Mójcza; 8200 - na N od w. Dołki; !8201 - Milechowy k. wsi Bolmin; !8202 - na N od E kr. w. Bolmin; 8211 - na N od wsi Bocheniec; !8212 - na S od w. Bolmin (EAZARSKI 2011); !8223 - na S od w. Mosty; !8320 - na SE od SE kr. w. Mosty; !8322 - na E od w. Lipowica; !8323 - na SW od W kr. w. Brzeziny, Las Nidzki; 8401 - na S od ul. Leśniówka, Kielce, Kowalski Las; !8402 - na NE od E kr. msc. Kielce - Dyminy; !8411 - na N od w. Bilcza - Podgórze, Kowalski Las; 8412 - na N od w. Bilcza - Zastawie; 8413 - na S od S kr. w. Suków - Modrzewie; !8421 - na NW od W kr. w. Bieleckie Młyny; !8422 - na SE od w. Bilcza - Zastawie; 8423 - E kr. w. Kuby - Młyny; !8430 - na S od E kr. w. Nida.

Not.: Bróż \& DurCZaK 1978; Bróż \& PrZeMYSKI 1981; Bróż i in. 1990.

Cimicifuga europaea - Świetliste dąbrowy, zbiorowiska pośrednie między świetlistymi dąbrowami a grądami, bory mieszane; ch; zagr.: NT; zagr. r.: NT. 22 stan.: 7221 - na E od w. Wesoła, G. Wesołowska; 7230 - na E od w. Zakrucze, G. Bolmińska; !7231 - na NW od w. Milechowy, m. Brodową a G. Milechowską; 7323 - na N od msc. Kilece - Białogon: g. Brusznia, g. Marmurek, G. Stokowa; !7330 - na SE od E kr. w. Gałęzice, G. Żakowa; !7332 - na NW od msc. Zgórsko; 7333 - na E od st. kol. Słowik; 8200 - na N od w. Dołki, g. Brogowica; 8201 - Milechowy k. wsi Bolmin; 8211 - na E od w. Bocheniec, Bocheńska G. (ŁAZARSKI 2011); !8212 - na S od w. Bolmin, Wzg. Wilkomijskie, (ŁAZARSKI 2011); 8213 - na S od w. Korzecko - Zarośle, Grzywy Korzeckowskie; 8300 - na N od w. Skiby, G. Wsiowa; 8301 - na N od msc. Chęciny, g. Zelejowa; 8302 - Bolechowice, Czerwona G., g. Berberysówka; 8310 - na S od E kr. w. Korzecko, Grzywy Korzeckowskie; 8311 - na S od w. Podzamcze, Grzywy Korzeckowskie; !8401 - na S od ul. Leśniówka, Kielce, Kowalski Las; 8402 - na S od W kr. w. Suków - Babie, N zbocze Babiej G.; !8411 - na N od w. Bilcza - Podgórze, Kowalski Las; !8413 - na S od S kr. w. Suków - Modrzewie; 8422 - na NW od W kr. w. Kuby - Młyny.

Not.: BŁoński 1892; MASSALski 1962; GŁAZeK 1976a; Bróż \& PrZemyski 1981; WnuK 1986; Bróż 1988; BRÓŻ \& PRZEMYSKI 1988.

Corallorhiza trifida - Buczyny, grądy; CH; zagr.: VU; zagr. r.: EN. 6 stan.: !7321 - na S od W kr. w. Jaworznia; !7322 - na S od E kr. w. Jaworznia; !7331 - na N od E kr. w. Szewce; 7332 - na N od msc. Zgórsko; 7333 - na $\mathrm{N}$ od E kr. w. Zagrody; 8302 - na $\mathrm{N}$ od w. Bolechowice, W zbocze g. Malik.

Not.: P. Zgórskie, g. Patrol, leg. Bróż \& Molendowska 1986 (KTC); MASSALSKI 1962; Bróż 1981a; Bróż i in. 1990; CIOSEK \& BzDon 2000.

! Corydalis cava - Grąd; zagr. r.: VU. 2 stan.: 7430 - na SE od msc. Kielce - Białogon (P. Posłowickie); 8302 - Czerwona G., N zbocze. 
Corydalis solida - Łęgi i zarośla łęgowe, grądy; zagr. r.: NT. 8 stan.: !8200 - na NW od w. Bocheniec; !8201 - Milechowy k. wsi Bolmin; !8211 - Bocheniec, dol. Wiernej Rz. (ŁAZARSKI 2011); !8212 - na S od w. Bolmin, Wzg. Wilkomijskie (ŁAZARSKI 2011); !8213 - na W od w. Mosty; !8301 - Zelejowa; !8302 - Czerwona G., N zbocze; !8320 - na SE od SE kr. w. Mosty.

Not.: BRÓż \& PRZEMYSKI 1983-1985a; BRÓż i in. 1990.

Cotoneaster integerrimus - Zarośla ciepłolubne, świetliste dąbrowy, bory mieszane; zagr. r.: NT; gat. górski (ogólnogr.). 19 stan.: !7221 - na E od w. Wesoła, Wesołowska G.; 7230 - na E od w. Zakrucze (g. Brodowa, Bolmińska G.); !7231 - na N od w. Milechowy, m. Brodową a Milechowską G.; 7232 - Miedzianka, g. Miedzianka; !7233 - na N od w. Polichno; 8200 - na N od w. Dołki, g. Brogowica; 8201 - Milechowy k. wsi Bolmin; 8202 - na N od E kr. w. Bolmin, Grząby Bolmińskie; !8203 - Polichno; 8211 - na E od w. Bocheniec, Bocheńska G. (ŁAZArski 2011); 8212 - na S od w. Bolmin, Wzg. Wilkomijskie; 8213 - na S od w. Korzecko - Zarośle, Grzywy Korzeckowskie; !8300 - na NW od msc. Chęciny, g. Sosnówka, g. Zegzela; 8301 - na N od msc. Chęciny, g. Zelejowa; 8310 - na S od E kr. w. Korzecko, Grzywy Korzeckowskie; na N od E kr. w. Korzecko, g. Rzepka; 8311 - na S od msc. Chęciny; !8312 - na S od w. Radkowice; !8313 - na S od SE kr. w. Wola Murowana; !8322 - na W od w. Lipowica, g. Grabówki.

Not.: rezerwat G. Zelejowa, leg. Mazur 1973 (KTC); Czerwona G., leg. Utnik \& Bróż 1978 (KTC); MASSALSKI 1962; Browicz \& GostyŃsKa 1963a; MAZUR 1975; GŁAZEK 1976a; Bróż 1986, 1988; Bróż \& PRZEMYSKI 1989; BRÓŻ i in. 1990.

Cotoneaster niger - Zarośla ciepłolubne; zagr. r.: VU. 1 stan.: !8202 - na N od E kr. w. Bolmin, Grząby Bolmińskie.

Not.: Massalski 1962; BRowicZ \& GostyŃSKa 1963b; WNUK 1986; BRÓż 1988.

! Cucubalus baccifer - Zarośla w dolinie rzeki. 1 stan.: 8422 - na SE od w. Bilcza - Zastawie.

! Dactylis polygama - Grądy, zarośla łęgowe; zagr. r.: EN. 5 stan.: 7223 - na N od w. Skałka; 7431 - na N od W kr. msc. Kielce - Dyminy; 8212 - na S od w. Bolmin, u podn. Wzg. Wilkomijskich; 8311 - na N od w. Podzamcze; 8402 - na S od W kr. w. Suków - Babie.

Dactylorhiza fuchsii - Skraje łęgów, wilgotna łąka; CH; zagr. r.: EN. 3 stan.: !7222 - na N od w. Lesica k. Bławatkowa; !7230 - na W od w. Kopaniny, dol. Wiernej Rz.; 8412 - na N od w. Bilcza - Zastawie, dol. Chodczy.

Not.: m. Bilczą a Dyminami, leg. Kaznowski 1925 (KRAM); JAGIEŁŁo 1986-1987.

Daphne mezereum - Lasy liściaste, bory mieszane; ch. 36 stan.: !7221 - na E od w. Wesoła; !7230 na N od osady Nowiny, k. w. Milechowy, g. Brodowa; !7231 - na NW od w. Milechowy; !7233 - na N od w. Polichno; !7320 - na SW od W kr. w. Łaziska k. Piekoszowa; !7321 - na S od W kr. w. Jaworznia; !7322 - na S od E kr. w. Jaworznia; 7323 - na N od msc. Kielce - Białogon; !7330 - na SE od E kr. w. Gałęzice, G. Żakowa; !7331 - na S od E kr. w. Zawada; 7332 - na NW od msc. Zgórsko; 7333 - Słowik - Markowizna; 7430 - na N od W kr. ul. Posłowickiej, Kielce; 7431 - na N od ul. Leśniówka, Kielce; 7432 - na S od msc. Kielce - Pod Telegrafem; !7433 - Mójcza; !8200 - na N od w. Dołki; 8201 - Milechowy k. wsi Bolmin; !8202 - na N od E kr. w. Bolmin; !8211 - na N od wsi Bocheniec; !8212 - na S od w. Bolmin; !8213 - na S od w. Korzecko - Zarośle, Grzywy Korzeckowskie; !8300 - na N od w. Skiby, G. Wsiowa; 8302 - Bolechowice; !8310 - na S od E kr. w. Korzecko, Grzywy Korzeckowskie; 8311 - na S od msc. Chęciny; !8400 - na S od ul. Na Stole, Kielce, Kowalski Las; !8401 - na S od ul. Leśniówka, Kielce, Kowalski Las; !8402 - na S od W kr. w. Suków - Babie, N zbocze Babiej G.; !8403 - Suków; !8410 Kowala Duża; !8411 - Bilcza - Podgórze; !8412 - na N od w. Bilcza - Zastawie; !8413 - na S od S kr. w. Suków - Modrzewie; !8421 - na NW od w. Piaseczna Górka; !8422 - na NW od W kr. w. Kuby - Młyny.

Not.: DrYMMER 1890; BŁoŃSKI 1892; BRÓŻ i in. 1990.

Dentaria bulbifera - Grądy, buczyny. 4 stan.: !7322 - na S od E kr. w. Jaworznia, N zbocze G. Pruszkowej; 7332 - na N od msc. Zgórsko, N zbocze g. Patrol; 7333 - na E od st. kol. Słowik; !7430 - na N od W kr. ul. Posłowickiej, Kielce, P. Posłowickie.

Not.: MASSALSKI 1962; BRÓż \& PrZEMYSKI 1981; BRÓż i in. 1990. 
Dentaria enneaphyllos - Grądy, buczyny; zagr. r: VU; gat. górski (regl.). 4 stan.: 7322 - na S od E kr. w. Jaworznia, N zbocze G. Pruszkowej; 7332 - na N od msc. Zgórsko, N zbocze g. Patrol; 7333 - na E od st. kol. Słowik; !7430 - na N od W kr. ul. Posłowickiej, Kielce, P. Posłowickie.

Not.: BRóż i in. 1990; BRÓż \& MACIEJCZAK 1991.

! Deschampsia flexuosa - Świeży bór sosnowy. 2 stan.: 8212 - na E od msc. Nowa Wieś k. Bocheńca, skarpa doliny Białej Nidy; 8413 - na N od w. Kuby-Młyny.

Digitalis grandiflora - Dąbrowy, grądy, bory mieszane, ciepłolubne okrajki; ch; zagr. r: NT. 23 stan.: 7230 - na E od w. Zakrucze; 7231 - na NW od w. Milechowy; 7323 - Kielce - Białogon, g. Brusznia; !7330 - na SE od E kr. w. Gałęzice, G. Żakowa; 7332 - na N od msc. Zgórsko; !7333 - na E od st. kol. Słowik; 8200 - na N od w. Dołki; 8201 - Milechowy k. wsi Bolmin; 8202 - na N od E kr. w. Bolmin; 8211 - na N od wsi Bocheniec; 8212 - na S od w. Bolmin, Wzg. Wilkomijskie; 8213 - na S od w. Korzecko - Zarośle, Grzywy Korzeckowskie; !8223 - na S od w. Mosty, g. Bzowica; !8300 - na N od w. Skiby, G. Wsiowa; 8310 - na S od E kr. w. Korzecko, Grzywy Korzeckowskie; !8320 - na SE od SE kr. w. Mosty; !8400 - na S od ul. Na Stole, Kielce, Kowalski Las; 8401 - na S od ul. Leśniówka, Kielce, Kowalski Las; 8402 - na S od W kr. w. Suków - Babie, N zbocze Babiej G.; !8410 - Kowala Duża; !8411 - na N od w. Bilcza - Podgórze, Kowalski Las; 8412 - na S od W kr. w. Suków - Babie, S zbocze Babiej G.; !8421 - na NW od w. Piaseczna Górka.

Not.: Drymmer 1890; Bróż \& DuRCZAK 1978; Bróż \& PrZemyski 1981; Wnuk 1986.

!Dryopteris cristata - Podtorfione olsy, torfowiska; zagr. r: VU. 4 stan.: 7222 - na NW od w. Lesica; 7230 - na W od w. Kopaniny, dol. Wiernej Rz.; 8421 - na S od W kr. w. Bieleckie Młyny; 8423 - na W od NW kr. w. Marzysz-Kiełków, dol. Czarnej Nidy.

Epipactis helleborine - Bory sosnowe, bory mieszane, grądy, łęgi, dąbrowy i ich skraje, zarośla, pobocza dróg wiodących przez lasy; ch. 50 stan.: !7221 - na E od w. Wesoła; !7222 - na N od w. Bławatków; !7223 - W kr. w. Rykoszyn; !7230 - na E od w. Zakrucze; !7231 - na NW od osady Gajówka; !7232 - Miedzianka; !7233 - na N od w. Polichno; !7312 - Szczukowice; !7320 - na SW od W kr. w. Łaziska k. Piekoszowa; !7321 - na S od W kr. w. Jaworznia; !7322 - Janów; 7323 - na N od msc. Kielce - Białogon; !7330 - E kr. w. Gałęzice; !7331 - na S od w. Szewce, g. Okrąglica; 7332 - na NW od msc. Zgórsko; 7333 - Słowik - Markowizna; 7430 - na N od W kr. ul. Posłowickiej, Kielce; 7431 na $\mathrm{N}$ od ul. Leśniówka, Kielce; 7432 - na S od msc. Kielce - Pod Telegrafem; !7433 - Mójcza; !8200 - na S od w. Zakrucze; 8201 - Milechowy k. w. Bolmin; !8202 - na N od E kr. w. Bolmin; !8203 Polichno; 8211 - na N od wsi Bocheniec; 8212 - na S od w. Bolmin, Wzg. Wilkomijskie; 8213 - na N od w. Mosty, Grzywy Korzeckowskie; !8223 - na S od w. Mosty; !8300 - na N od w. Skiby, G. Wsiowa; !8301 - na N od msc. Chęciny, g. Zelejowa; !8302 - Bolechowice; !8303 - na S od w. Nowiny, gm. Sitkówka - Nowiny; !8310 - na S od E kr. w. Korzecko, Grzywy Korzeckowskie; !8311 - na S od msc. Chęciny; !8313 - W kr. w. Brzeziny; !8320 - na SE od SE kr. w. Mosty; !8322 - na E od w. Lipowica; !8323 - na SW od W kr. w. Brzeziny, Las Nidzki; !8400 - na S od ul. Na Stole, Kielce, Kowalski Las; !8401 - na S od msc. Kielce - Dyminy; !8402 - na NE od E kr. msc. Kielce - Dyminy; !8410 - Kowala Duża; !8411 - na N od w. Bilcza - Podgórze, Kowalski Las; !8412 - na N od w. Bilcza - Zastawie; !8413 - na S od S kr. w. Suków - Modrzewie; 8420 - centr. cz. w. Brzeziny; !8421 - na NW od w. Piaseczna Górka; !8422 - na SE od w. Bilcza - Zastawie; !8423 - E kr. w. Kuby - Młyny; !8430 - na S od E kr. w. Nida.

Not.: MASSALSKI 1962; BRÓŻ \& DurCZAK 1978; BRÓż 1986; Bróż i in. 1990.

Epipactis atrorubens - Bory sosnowe, bory mieszane; ch; zagr.: NT; zagr. r: VU. 10 stan.: !7230 - na SE od w. Kopaniny, podn. Bolmińskiej G.; !8200 - na N od w. Dołki, g. Brogowica; 8212 - E kr. w. Kresy k. Bolmina (ŁAZARSKI 2011); !8303 - na S od w. Nowiny, gm. Sitkówka - Nowiny; !8323 - na SW od W kr. w. Brzeziny, Las Nidzki; !8401 - na S od msc. Kielce - Dyminy; !8411 - na NE od w. Bilcza - Podgórze; !8412 - na N od w. Bilcza - Zastawie; !8421 - na NW od W kr. w. Bieleckie Młyny; !8430 - na S od E kr. w. Nida.

Not.: Bróż \& DurCZAK 1978; Bróż 1986; BRÓŻ i in. 1990. 
Euphorbia amygdaloides - Grądy, buczyny, dąbrowy, bory mieszane; zagr. r: NT. 30 stan.: 7230 - na E od w. Zakrucze (g. Brodowa); 7231 - na W od osady Gajówka; !7320 - na SW od W kr. w. Łaziska k. Piekoszowa; 7322 - na N od w. Janów, Podzamecka G.; 7330 - na SE od E kr. w. Gałęzice, G. Żakowa; 7331 - na S od w. Szewce, g. Okraglica; 7333 - na E od st. kol. Słowik; !7431 - na S od msc. Kielce Kawetczyzna; 7432 - na S od msc. Kielce - Pod Telegrafem; !8201 - na N od w. Milechowy; 8202 - na N od E kr. w. Bolmin, Grząby Bolmińskie; 8212 - na NW od wsi Choiny, Wzg. Wilkomijskie; 8213 - na S od w. Korzecko - Zarośle, Grzywy Korzeckowskie; 8301 - na N od msc. Chęciny, g. Zelejowa; 8302 - na N od w. Bolechowice, Czerwona G.; !8311 - na S od w. Podzamcze, Grzywy Korzeckowskie; 8320 - na SE od SE kr. w. Mosty; Tokarnia, las na terenie skansenu; !8400 - na S od ul. Na Stole, Kielce, Kowalski Las; 8410 - na S od E kr. w. Kowala Duża; !8411 - Bilcza - Podgórze; !8412 - na S od W kr. w. Suków - Babie, S zbocze Babiej G.

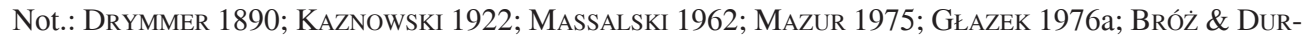
CZAK 1978; BRÓŻ \& PRZEMYSKI 1987; BRÓŻ i in. 1990.

Festuca amethystina subsp. ritschlii - Świetliste dąbrowy, bory mieszane; CH; zagr.: EN; EN; zagr. r: VU. 6 stan.: 7230 - na NW od NW kr. w. Milechowy, szczytowa część końcowego wzniesienia Grząb Bolmińskich (oddz. 230d, h, Nadl. Kielce); 7231 - na NW od osady Gajówka, N zbocze Milechowskiej G.; 8200 - na NW od w. Dołki, g. Brogowica; 8211 - na NE od w. Bocheniec, Bocheńska G.; !8212 - na NW od w. Choiny, Wzg. Wilkomijskie (ŁAZARski 2016b); 8213 - na NW od W kr. w. Mosty, g. Chrostynia, g. Grzywy, Grzywy Korzeckowskie.

Not.: Bróż 1981a; JAKUBOWSKA-GABARA 1994.

! Galanthus nivalis - Grąd na skarpie. ch; zagr. r.: VU. 1 stan.: 8422 - na N od w. Łabędziów, dol. Czarnej Nidy.

Galium rotundifolium - Jedliny, bór mieszany; zagr.: NT; zagr. r: EN; gat. górski (regl.). 4 stan.: 7333 - na E od st. kol. Słowik; 7430 - na N od msc. Posłowice; 7431 - na N od ul. Leśniówka, Kielce; !8323 - na N od W kr. w. Nida, Niedziańska G.

Not.: G. Foltańskiego, leg. Bróż \& Hładka 1985 (KTC); P. Posłowickie: g. Biesak, leg. Bróż \& Molendowski 1986 (KTC); P. Posłowickie: g. Pierścienica, leg. Bróż \& Molendowski 1986 (KTC); KazNowski 1922; CZUBiŃSKA 1962; MASSALSKI 1962; BRÓż 1981b; BRÓŻ i in. 1990.

Geranium sylvaticum - Grądy; zagr.: NT; zagr. r.: VU. 11 stan.: !7221 - na E od w. Wesoła, Wesołowska G.; !7230 - na E od w. Zakrucze (g. Brodowa); 7231 - na W od osady Gajówka; 7323 - na N od msc. Kielce - Białogon, g. Brusznia; !8200 - na N od w. Dołki, g. Brogowica; !8202 - na N od E kr. w. Bolmin, Grząby Bolmińskie; !8211 - na N od wsi Bocheniec, Bocheńska G.; 8212 - na W od w. Choiny, Wzg. Wilkomijskie; !8213 - na N od w. Mosty, Grzywy Korzeckowskie; !8310 - na S od E kr. w. Korzecko, Grzywy Korzeckowskie.

Not.: MASSALSKI 1962; BRÓż 1988.

Glechoma hirsuta - Grądy i zbiorowiska pośrednie między grądami a świetlistymi dąbrowami; zagr. r.: DD. 1 stan.: 8300 - na NE od w. Skiby, G. Wsiowa.

Not.: GŁAZEK 1976a; Bróż 1981a; Bróż 1988; Bróż \& MACIEJCZAK 1991.

! Goodyera repens - Świeże i wilgotne bory sosnowe, bory mieszane; CH; zagr.: NT; zagr. r.: VU; gat. górski (ogólnogr.). 10 stan.: wykaz stanowisk w pracy ŁAZARSKI 2020.

Gypsophila fastigiata - Prześwietlony bór sosnowy. 2 stan.: !7230 - na NE od w. Zakrucze, u podn. g. Brodowej; !8200 - na E od w. Zakrucze.

Not.: BRóż i in. 1990.

! Hierochlö̈ odorata - Bór sosnowy na zboczu doliny rzecznej, przydroże i rów przydrożny; ch; zagr.: VU; zagr. r.: CR. 2 stan.: 8212 - na E od msc. Nowa Wieś k. Bocheńca, zbocze doliny Białej Nidy; 8401 - Kielce, ul. Ściegiennego, przy przystanku Piekarnia. 
Hypochoeris maculata - Bory mieszane, bory sosnowe; zagr. r.: VU. 6 stan.: !7223 - W kr. w. Rykoszyn; !7231 - na NW od w. Milechowy, m. Brodową a Milechowską G.; 8200 - na N od w. Dołki, g. Brogowica; 8201 - na S od osady Nowiny; !8211 - na NE od w. Bocheniec, Bocheńska G.; !8402 - na S od W kr. w. Suków - Babie, W zbocze Babiej G.

Not.: g. Brogowica, leg. Walas \& Bróż 1978 (KTC); P. Posłowickie, obr. Dyminy, oddz. 55, leg. Czernicka \& Bróż 1978 (KTC); BRóż i in. 1990.

Inula conyza - Świetliste dąbrowy (także zdegradowane postacie tego zbiorowiska); zagr. r.: EN. 2 stan.: 8213 - na S od w. Korzecko - Zarośle, Grzywy Korzeckowskie; !8310 - na NE od E kr. w. Mosty, Grzywy Korzeckowskie.

Not.: Grzywy Korzeckowskie, leg. Rajkowska \& Bróż 1977 (KTC); MASSALSKI 1962; BRóż 1981b.

Inula hirta - Świetlista dąbrowa; zagr.: EN; zagr. r.: VU. 1 stan.: !8200 - na N od w. Dołki, g. Brogowica, W zbocze.

Not.: MASSALSKI 1962.

Inula salicina - Świetliste dąbrowy, ciepłolubne zarośla i okrajki, wilgotne łąki; zagr. r.: NT. 13 stan.: 7221 - na E od w. Wesoła, Wesołowska G.; 77223 - W kr. w. Rykoszyn; 7230 - na E od w. Zakrucze (g. Brodowa, Bolmińska G.); 8200 - na N od w. Dołki, g. Brogowica; 8211 - na N od wsi Bocheniec; 8213 - na N od w. Mosty, Grzywy Korzeckowskie; !8221 - na NE od w. Tokarnia; 8310 - na S od E kr. w. Korzecko, Grzywy Korzeckowskie; na N od E kr. w. Korzecko, g. Rzepka; 8311 - Chęciny, g. Zamkowa; !8313 - na S od SE kr. w. Wola Murowana; !8320 - Tokarnia; 8401 - na S od ul. Leśniówka, Kielce, Kowalski Las; !8411 - na N od w. Bilcza - Podgórze, Kowalski Las.

Not.: BRÓż \& DuRCZAK 1978; BRÓż 1981b; BRóż \& PRZEMYSKI 1988.

Isopyrum thalictroides - Grądy, buczyny. 8 stan.: 7231 - na NW od w. Milechowy, m. Brodową a Milechowską G.; !7322 - na S od E kr. w. Jaworznia; 7332 - na NW od msc. Zgórsko; !7333 - na E od st. kol. Słowik; !7430 - na N od W kr. ul. Posłowickiej, Kielce; 8302 - Czerwona G., N zbocze; !8320 - na SE od SE kr. w. Mosty; !8422 - na N od w. Łabędziów, dol. Czarnej Nidy.

Not.: P. Zgórskie, obr. Dyminy, oddz. 78, leg. Czernicka \& Bróż 1978 (KTC); P. Zgórskie, G. Słowikowska, leg. Bróż \& Molendowska 1985 (KTC); BRÓż 1981b.

Laserpitium prutenicum - Świetlista dąbrowa; zagr.: VU; zagr. r.: VU. 1 stan.: !8420 - na NE od kośc. we w. Brzeziny.

Not.: Dobromyśl k. Zalesia pod Kielcami, leg. Molendowska \& Bróż 1985 (KTC); Bróż \& PrzeMYSKI 1988.

Lathraea squamaria - Grądy. 8 stan.: !7231 - na W od osady Gajówka (m. Brodową a Milechowską G.); 7332 - na N od msc. Zgórsko; !7333 - na E od st. kol. Słowik; 7430 - na N od W kr. ul. Posłowickiej, Kielce; 7431 - na S od msc. Kielce - Kawetczyzna; 7432 - na NW od W kr. w. Suków - Borki; !8201 - na N od w. Milechowy (Grząby Bolmińskie); !8302 - Czerwona G., N i E zbocze.

Not.: Bróż 1981a; Bróż i in. 1990.

Lathyrus pisiformis - Świetliste dąbrowy, bory mieszane, ciepłolubne zarośla i okrajki; CH; zagr.: VU; EN; zagr. r.: CR. 9 stan.: 7230 - na NW od NW kr. w. Milechowy, szczytowa część końcowego wzniesienia Grząb Bolmińskich (oddz. 230d, Nadl. Kielce); 7231 - na NW od osady Gajówka, S zbocze wzniesienia, Grząby Bolmińskie; pozostałe stanowiska wymienione w pracach: HERBICH \& ŁAZARSKI 2014; ŁAZARSKI 2014.

Not.: wzg. wapienne Duża Sowa (=g. Miedzianka), k. Miedzianki, leg. Kaznowski 1923 (KRAM); wzg. wapienne Bolmińskie k. Małogoszcza, leg. Kaznowski 1924 (KRAM); Babia G. za Dyminami leg. Kaznowski 1925 (KRAM); G. Wilkomija nad Białą Nidą za Jedlnicą, leg. Kaznowski 1928 (KRAM); MASSALSKI 1962; GŁAZEK 1976b; BRÓż \& DuRCZAK 1978; BRÓż 1981a; BRÓŻ \& PRZEMYSKI 1988; HeRBICH 1988.

Ledum palustre - Bory bagienne, obrzeża torfowisk przejściowych; ch. 8 stan.: !7222 - na NE od E kr. w. Lesica; na NW od w. Skałka; 7223 - na N od w. Skałka; !7230 - na N od w. Zakrucze, dol. Wiernej 
Rz.; !8401 - na S od W kr. msc. Kielce - Dyminy; !8411 - na NE od w. Bilcza - Podgórze; !8412 - na N od w. Bilcza - Zastawie; !8413 - na NW od NW kr. w. Marzysz, dol. Lubrzanki; 8423 - na W od NW kr. w. Marzysz - Kiełków, dol. Czarnej Nidy.

Not.: DRYMMER 1890.

Lilium martagon - Grądy, świetliste dąbrowy, bory mieszane, jedliny, ciepłolubne zarośla, grądowe zarośla; CH. 40 stan.: !7221 - na E od w. Wesoła, Wesołowska G.; !7222 - na N od w. Bławatków; 7230 - na E od w. Zakrucze (g. Brodowa i Bolmińska G.); 7231 - na N od w. Milechowy, Milechowska G.; 17233 - na NW od E kr. w. Skiby; 7321 - na S od W kr. w. Jaworznia; !7322 - na S od E kr. w. Jaworznia; 7323 - Kielce - Białogon, G. Stokowa; g. Marmurek; g. Brusznia; !7330 - na SE od E kr. w. Gałęzice, G. Żakowa; 7331 - na S od w. Szewce, g. Okrąglica; 7332 - na NW od msc. Zgórsko; 7333 - na E od st. kol. Słowik; 7430 - na N od W kr. ul. Posłowickiej, Kielce; 7431 - na N od ul. Leśniówka, Kielce; 7432 - na NW od W kr. w. Suków - Borki; 8200 - na N od w. Dołki, g. Brogowica; 8201 - na W od w. Milechowy, Bocheńska G.; 8202 - na N od E kr. w. Bolmin, Grząby Bolmińskie; 8211 - na N od wsi Bocheniec, Bocheńska G.; 8212 - na W od w. Choiny, Wzg. Wilkomijskie; 8213 - na S od w. Korzecko - Zarośle, Grzywy Korzeckowskie; !8223 - na S od w. Mosty, g. Bzowica; 8300 - na N od w. Skiby, G. Wsiowa; na NW od msc. Chęciny, g. Sosnówka; 8301 - na N od msc. Chęciny, g. Zelejowa; 8302 - Bolechowice, Czerwona G., g. Berberysówka; !8303 - na S od w. Nowiny, gm. Sitkówka - Nowiny; 8310 - na S od E kr. w. Korzecko, Grzywy Korzeckowskie; 8311 - na S od w. Podzamcze, Grzywy Korzeckowskie; !8320 - na SE od SE kr. w. Mosty; !8320 - Tokarnia, las w skansenie; 8323 - na N od W kr. w. Nida, g. Hosa; 8400 - na S od ul. Na Stole, Kielce, Kowalski Las; !8401 - na S od ul. Leśniówka, Kielce, Kowalski Las; !8402 - na S od W kr. w. Suków - Babie, W zbocze Babiej G.; !8403 - na E od w. Suków, dol. Lubrzanki; 8410 - na S od E kr. w. Kowala Duża; !8411 - na N od w. Bilcza - Podgórze, Kowalski Las; 8412 - na S od W kr. w. Suków - Babie, S zbocze Babiej G.; !8413 - na S od S kr. w. Suków - Modrzewie; !8420 - na S od centr. cz. w. Brzeziny; !8422 - na NW od W kr. w. Kuby - Młyny.

Not.: Bróż \& DuRCZAK 1978; BRÓŻ \& PRZEMYSKi 1981; WNUK 1986.

Lycopodium annotinum - Bory sosnowe, jedliny; ch; zagr.: NT. 7 stan.: 77330 - na E od E kr. w. Gałęzice; 7430 - na N od W kr. ul. Posłowickiej, Kielce; 7431 - na S od msc. Kielce - Kawetczyzna; 7432 - na S od msc. Kielce - Pod Telegrafem; !7433 - Mójcza; !8412 - na N od w. Bilcza - Zastawie; !8413 - na S od S kr. w. Suków-Modrzewie.

Not.: DrYMMER 1890; BRÓż i in. 1990.

Lycopodium clavatum - Bory sosnowe; ch; zagr.: NT. 4 stan.: !7231 - na NW od osady Gajówka, na N od rezerwatu Milechowy; 8202 - na NW od w. Jedlnica, Grząby Bolmińskie; !8411 - na NE od w. Bilcza - Podgórze; !8413 - na S od S kr. w. Suków-Modrzewie.

Not.: DrYMMER 1890; BRÓż i in. 1990.

Matteucia struthiopteris - Zarośla łęgowe; ch; zagr. r.: VU; gat. górski (podgr.). 5 stan.: 7333 - Słowik, dol. Bobrzy; !8302 - na E od msc. Czerwona G., dol. Bobrzyczki; !8312 - na W od NE kr. w. Lipowica; !8402 - na S od E kr. msc. Kielce - Dyminy, dol. Chodczy; 8423 - na E od w. Kuby Młyny, dol. Czarnej Nidy.

Not.: KAMIEŃSKI 1885; Rostafiński 1886; DrymMer 1890; MASSALSKI 1962; Bróż 1981a; Bróż i in. 1990.

Melandrium rubrum - Grąd; zagr. r.: NT. 1 stan.: 8211 - na NW od mostu we w. Bocheniec (ŁAZARSKI 2011).

Melittis melissophyllum - Świetliste dąbrowy, bory mieszane, grądy zboczowe; ch. 35 stan.: !7221 - na E od w. Wesoła, G. Wesołowska; !7223 - W kr. w. Rykoszyn; !7230 - na E od w. Zakrucze; !7231 - na W od osady Gajówka; !7320 - na SW od W kr. w. Łaziska k. Piekoszowa; !7321 - Jaworznia, g. Moczydła; !7322 - na N od w. Janów, Podzamecka G.; 7323 - Kielce - Białogon, Stokowa G.; g. Marmurek; g. Brusznia; !7330 - na SE od E kr. w. Gałęzice, G. Żakowa; !7331 - na S od w. Szewce, g. Okrąglica; 7332 - na NW od msc. Zgórsko; 7333 - na E od st. kol. Słowik; !7430 - na N od W kr. ul. 
Posłowickiej, Kielce; !7431 - na N od ul. Leśniówka, Kielce; 7432 - na NW od W kr. w. Suków - Borki; !8200 - na N od w. Dołki, g. Brogowica; 8201 - na W od w. Milechowy; !8202 - na N od E kr. w. Bolmin, Grząby Bolmińskie; !8203 - Polichno; 8211 - na N od wsi Bocheniec; 8212 - na S od w. Bolmin, Wzg. Wilkomijskie; 8213 - na S od w. Korzecko - Zarośle, Grzywy Korzeckowskie; !8223 - na S od w. Mosty, g. Bzowica; 8300 - na N od w. Skiby, G. Wsiowa; !8302 - Bolechowice; !8310 - na S od E kr. w. Korzecko, Grzywy Korzeckowskie; 8311 - na S od w. Podzamcze, Grzywy Korzeckowskie; !8320 - na SE od SE kr. w. Mosty; !8400 - na S od ul. Na Stole, Kielce, Kowalski Las; !8401 - na S od ul. Leśniówka, Kielce, Kowalski Las; !8402 - na S od W kr. w. Suków - Babie, N zbocze Babiej G.; 8410 - na S od E kr. w. Kowala Duża; !8411 - na N i S od w. Bilcza - Podgórze; !8412 - na S od W kr. w. Suków - Babie, S zbocze Babiej G.; !8422 - na NW od W kr. w. Kuby - Młyny.

Not.: DryMMER 1890; MASSALSKI 1962; BRÓż 1986; BRÓż i in. 1990.

Moneses uniflora - Bory sosnowe; ch; zagr.: NT. 19 stan.: !7222 - Bławatków; 7230 - na N od w. Zakrucze; !7232 - Miedzianka; !7233 - na N od w. Polichno; !7330 - na N od NW kr. w. Skiby; 7333 - na SE od st. kol. Słowik; !8200 - na N od w. Dołki; !8202 - na N od w. Jedlnica, Grząby Bolmińskie; 8212 - na S od w. Bolmin; 8320 - na N od w. Tokarnia; 8322 - na E od w. Lipowica; !8323 - na SW od W kr. w. Brzeziny, Las Nidzki; !8401 - na S od W kr. msc. Kielce - Dyminy; 8402 - na NE od E kr. msc. Kielce - Dyminy; !8411 - na N od w. Bilcza - Podgórze, Kowalski Las; !8412 - na N od w. Bilcza - Zastawie; 8413 - na S od S kr. w. Suków - Modrzewie; !8422 - na SE od w. Bilcza - Zastawie; 8423 - E kr. w. Kuby - Młyny.

Not.: MASSALSKI 1962; BRÓż 1981b.

!Monotropa hypophegea - Bory mieszane; zagr.: DD. 5 stan.: 7231 - na W od osady Gajówka; 8303 - na S od w. Nowiny, gm. Sitkówka - Nowiny; 8401 - na S od ul. Leśniówka, Kielce, Kowalski Las; 8410 - na S od W kr. w. Kowala Mała; 8411 - na N od w. Bilcza - Podgórze, Kowalski Las.

Neottia nidus-avis - Grądy, buczyny, dąbrowy; ch. 27 stan.: 7230 - na E od w. Zakrucze (g. Brodowa i Bolmińska G.); 7231 - na W od osady Gajówka; 7321 - na S od W kr. w. Jaworznia; !7322 - na S od E kr. w. Jaworznia; 7323 - na N od msc. Kielce - Białogon, g. Marmurek; !7330 - na SE od E kr. w. Gałęzice, G. Żakowa; 7331 - na S od w. Szewce, g. Okrąglica; 7332 - na NW od msc. Zgórsko; 7333 - na E od st. kol. Słowik; 7430 - na N od W kr. ul. Posłowickiej, Kielce; !7431 - na N od ul. Leśniówka, Kielce; 7432 - na NW od W kr. w. Suków - Borki; !8200 - na N od w. Dołki, g. Brogowica; 8201 - na W od w. Milechowy; 8202 - na N od E kr. w. Bolmin, Grząby Bolmińskie; 8211 - na N od w. Bocheniec, Bocheńska G., !8212 - na S od w. Bolmin, Wzg. Wilkomijskie; 8213 - na S od w. Korzecko - Zarośle, Grzywy Korzeckowskie; !8223 - na S od w. Mosty, g. Bzowica; 8300 - na N od w. Skiby, G. Wsiowa; 8302 - Bolechowice; 8310 - na S od E kr. w. Korzecko, Grzywy Korzeckowskie; 8311 - na S od w. Podzamcze, Grzywy Korzeckowskie; !8320 - Tokarnia, las na terenie skansenu; !8401 - na S od ul. Leśniówka, Kielce, Kowalski Las; !8411 - na N od w. Bilcza - Podgórze, Kowalski Las; 8412 - na S od W kr. w. Suków-Babie, S zbocze Babiej G.

Not.: Drymmer 1890; MASSALSKi 1962; Bróż \& DuRCZAK 1978; BRÓż \& PrZEMYSKi 1981; Bróż i in. 1990; CIOSEK \& BZDON 2000.

Phegopteris connectilis - Brzegi strumieni, wąwozy w grądach. 7 stan.: 17322 - na S od E kr. w. Jaworznia; 7332 - na N od W kr. msc. Zgórsko; 7333 - na NE od msc. Słowik; 7431 - na S od msc. Kielce - Kawetczyzna; 7432 - na NW od W kr. w. Suków - Borki; !8213 - na N od w. Mosty, Grzywy Korzeckowskie; !8310 - na E od w. Korzecko, Grzywy Korzeckowskie.

Not.: BRÓż i in. 1990.

Polygala amara subsp. brachyptera - Bory sosnowe, bory mieszane, poręby; zagr. r.: VU; gat. górski (ogólnogr.). 8 stan.: 7230 - na NW od osady Nowiny k. w. Milechowy, g. Brodowa, W zbocze; !7322 - na N od w. Janów, Podzamecka G.; 7323 - na N od msc. Kielce - Białogon, N podn. G. Stokowej; 8211 - na N i NW od w. Bocheniec, Bocheńska G.; !8323 - na SW od W kr. w. Brzeziny, Las Nidzki; 8401 - na SE od ul. Nastole, Kielce, Las Kowalski; !8402 - na S od W kr. w. Suków - Babie, N zbocze Babiej G.; !8411 - na N od w. Bilcza - Podgórze, Kowalski Las. 
Not.: PawŁowski 1958; Massalski 1962; Bróż \& DurCZAK 1978; Bróż 1981b; Bróż 1988; Bróż \& PRZEMYSKI 1989.

Polygonatum verticillatum - Grądy, jedliny; zagr. r.: NT; gat. górski (regl.). 16 stan.: !7321 - na S od W kr. w. Jaworznia; !7322 - na S od E kr. w. Jaworznia; !7330 - na E od E kr. w. Gałęzice; !7331 - na S od E kr. w. Zawada; 7332 - na NW od msc. Zgórsko; !7333 - na E od st. kol. Słowik; 7430 - na N od W kr. ul. Posłowickiej, Kielce; 7431 - na S od msc. Kielce - Kawetczyzna; 7432 - na S od msc. Kielce - Pod Telegrafem; !8211 - na NW od ośrodka wypoczynkowego we w. Bocheniec, Bocheńska G. (ŁAZARsKI 2011); 8212 - na S od w. Bolmin, Wzg. Wilkomijskie (ŁAZARSKi 2011); !8402 - na S od W kr. w. Suków - Babie, N zbocze Babiej G.; !8403 - na E od w. Suków, dol. Lubrzanki; !8412 - na N od w. Bilcza - Zastawie; !8413 - na S od S kr. w. Suków - Modrzewie; !8421 - na NW od w. Piaseczna Górka.

Not.: Drymmer 1890; BRÓż \& DuRCZAK 1978; Bróż i in. 1990.

Polystichum aculeatum - Grądy, sporadycznie bory mieszane; CH; zagr. r.: VU; gat. górski (regl.). 8 stan.: 7231 - na N od osady Nowiny, k. w. Milechowy; !7322 - na SW od msc. Zalesie Stare; 7332 - na N od msc. Zgórsko; 7333 - na E od st. kol. Słowik; 7431 - na N od W kr. msc. Kielce - Dyminy, g. Hałasa; 7432 - na S od msc. Kielce - Pod Telegrafem, g. Hałasa; !8201 - na W od W kr. w. Bolmin, E zbocze Bocheńskiej G.; 8301 - na S od w. Zelejowa, N zbocze g. Zelejowa.

Not.: leg. Mazur 1974 (KTC); G. Wsiowa, leg. Utnik \& Bróż 1978 (KTC); P. Zgórskie, N zbocze g. Patrol, leg. Bróż \& Molendowska 1986 (KTC); g. Hałasa, leg. Chatys \& Bróż 1987 (KTC); KaznowsKi 1922; MASSAlski 1962; Mazur 1975; BRÓż 1977, 1988; Bróż \& PrZEMYsKi 1983-1985a, 1988; Bróż i in. 1990; BRÓż \& MACIEJCZAK 1991.

Platanthera bifolia - Bory mieszane, grądy, wilgotne łąki; ch. 6 stan.: !7332 - na W od msc. Zgórsko; !7431 - na S od msc. Kielce - Kawetczyzna; 7432 - na NW od W kr. w. Suków - Borki; !8200 - na N od w. Dołki; 8201 - na W od w. Milechowy; 8211 - na N od wsi Bocheniec.

Not.: Massalski 1962; Bróż \& DurczaK 1978; Bróż 1986; Bróż i in. 1990; CioseK \& Bzdon 2000.

Platanthera chlorantha - Bory mieszane, grądy, dąbrowy, buczyny; ch; zagr.: NT. 37 stan.: !7221 - na E od w. Wesoła; !7230 - na E od w. Zakrucze; !7231 - na W od osady Gajówka; !7233 - na NW od E kr. w. Skiby; !7320 - na SW od W kr. w. Łaziska k. Piekoszowa; !7321 - na S od W kr. w. Jaworznia; !7322 - na N od w. Janów, Podzamecka G.; !7323 - Kielce - Białogon, g. Marmurek; !7330 - na SE od E kr. w. Gałęzice, G. Żakowa; 77331 - na S od w. Szewce, g. Okrąglica; !7332 - na NW od msc. Zgórsko; 7333 - na E od st. kol. Słowik; !7430 - na N od W kr. ul. Posłowickiej, Kielce; !7431 - na N od ul. Leśniówka, Kielce; !7432 - na NW od W kr. w. Suków - Borki; !8200 - na N od w. Dołki; !8201 - na W od w. Milechowy; !8202 - na N od E kr. w. Bolmin; !8211 - na N od wsi Bocheniec; 8212 - na NW od wsi Choiny, Wzg. Wilkomijskie; !8213 - na S od w. Korzecko - Zarośle, Grzywy Korzeckowskie; !8300 - na N od w. Skiby, G. Wsiowa; !8302 - Bolechowice; !8303 - na S od w. Nowiny, gm. Sitkówka - Nowiny; !8310 - na S od E kr. w. Korzecko, Grzywy Korzeckowskie; !8320 - na SE od SE kr. w. Mosty; !8323 - na S od W kr. w. Brzeziny; !8400 - na S od ul. Na Stole, Kielce, Kowalski Las; !8401 - na S od ul. Leśniówka, Kielce, Kowalski Las; !8402 - na NE od E kr. msc. Kielce - Dyminy; !8410 - na S od E kr. w. Kowala Duża; !8411 - na N od w. Bilcza - Podgórze, Kowalski Las; !8412 - na N od w. Bilcza - Zastawie; !8413 - na S od S kr. w. Suków - Modrzewie; !8420 - centr. cz. w. Brzeziny; !8421 - na NW od w. Piaseczna Górka; !8430 - na S od E kr. w. Nida.

Not.: MASSALSKI 1962.

Pulmonaria angustifolia - Świetliste dąbrowy, ciepłolubne okrajki; zagr.: VU; zagr. r.: VU. 12 stan.: 7230 - na NW od w. Milechowy, m. Brodową a Milechowską G.; 7231 - na NW od osady Gajówka; 7323 - Kielce - Białogon, g. Brusznia; !7330 - na SE od E kr. w. Gałęzice, G. Żakowa; 8200 - na N od w. Dołki, g. Brogowica; 8211 - na N od wsi Bocheniec, Bocheńska G.; !8212 - na W od w. Choiny, Wz. Wilkomijskie; 8213 - na S od w. Korzecko - Zarośle, Grzywy Korzeckowskie; !8300 - na N od w. Skiby, G. Wsiowa; 8302 - SW zbocze Czerwonej G.; 8310 - na S od E kr. w. Korzecko, Grzywy Korzeckowskie.

Not.: GŁAZeK 1976a; Bróż \& DurCZAK 1978; Bróż \& PrZEMYsKi 1981; WNuK 1986. 
Pulsatilla patens subsp. patens - Prześwietlone bory sosnowe i bory mieszane, murawy kserotermiczne; CH; zagr.: EN; EN; zagr. r.: CR. 6* stan.: 7230 - na E od w. Zakrucze, W zbocze g. Brodowej (stanowiska nie ujęto w pracy ŁAZARSKI i in. 2018); 7323 - na N od msc. Kielce - Białogon, g. Marmurek, N zbocze; 8200 - na NW od w. Bocheniec, g. Brogowica; 8201 - na N od w. Bocheniec, W podn. G. Bocheńskiej; 8211 - na N od w. Bocheniec, W podn. G. Bocheńskiej; 8410 - na SW od w. Kowala (Łazarski \& Podgórska 2020). ${ }^{1}$

Not.: Kaznowski 1930; Massalski 1962; Bróż \& Durczak 1978; WNuK 1986; Bróż \& PrZemyski 1987; BRÓŻ \& MACIEJCZAK 1991.

!Pulsatilla $\times$ hackelii (Pulsatilla patens subsp. patens $\times$ P. pratensis) - Skraj boru mieszanego, przy drodze leśnej. 1 stan.: 8201 - na N od w. Bocheniec, W podn. G. Bocheńskiej (SzCZECIŃsKA i in. 2017; ŁAZARSKI i in. 2018).

Pulsatilla vernalis - Bór sosnowy; $\mathrm{CH}$; zagr.: EN; EN; zagr. r.: CR; gat. górski (ogólnogr.). 1 stan.: 8200 - na N od w. Dołki k. Bocheńca, SE podn. g. Brogowica (ŁAZARSKI i in. 2018).

Not.: KAZNOwSKI 1922, 1930; MASSALSKI 1962; BRÓŻ \& DURCZAK 1978; BRÓŻ 1981a; GRZYL \& RonIKIER 2011.

Pyrola chlorantha - Bory sosnowe, bory mieszane; ch. 27 stan.: !7222 - na N od w. Bławatków; !7232 - na NE od w. Miedzianka; !7233 - na N od w. Polichno; !7320 - na SW od W kr. w. Łaziska k. Piekoszowa; 7321 - na S od W kr. w. Jaworznia; 7332 - na N od msc. Zgórsko; 7430 - na N od W kr. ul. Posłowickiej, Kielce; 7431 - na S od msc. Kielce - Kawetczyzna; 8200 - na N od w. Dołki; !8202 - na N od E kr. w. Bolmin; !8203 - Polichno; !8212 - na S od w. Jedlnica; 8303 - na S od w. Nowiny, gm. Sitkówka - Nowiny; !8320 - na SE od w. Mosty; !8323 - na SW od W kr. w. Brzeziny, Las Nidzki; 8401 - na S od ul. Leśniówka, Kielce, Kowalski Las; !8411 - Bilcza - Podgórze; 8413 - na S od S kr. w. Suków - Modrzewie; 8423 - E kr. w. Kuby - Młyny; !8430 - na S od E kr. w. Nida.

Not.: Drymmer 1890; MASSALSKI 1962; Bróż \& DurCZAK 1978; Bróż \& PrZEMYSKI 1981; Bróż i in. 1990.

Pyrola minor - Bory sosnowe; ch. 28 stan.: !7222 - E kr. w. Lesica; !7223 - na N od w. Skałka; !7230 - na N od w. Zakrucze; !7232 - na NE od w. Miedzianka; !7233 - na N od w. Polichno; !7320 - na SW od W kr. w. Łaziska k. Piekoszowa; !7321 - W kr. w. Jaworznia; !7331 - na S od E kr. w. Zawada; 7333 - na SE od st. kol. Słowik; 7432 - na S od msc. Kielce - Pod Telegrafem; !7433 - Mójcza; !8200 - na NE od w. Dołki; 8302 - Bolechowice; !8320 - na N od w. Tokarnia; !8323 - na SW od W kr. w. Brzeziny, Las Nidzki; !8401 - na S od ul. Leśniówka, Kielce, Kowalski Las; !8413 - na S od S kr. w. Suków - Modrzewie; !8422 - na SE od w. Bilcza - Zastawie; !8423 - E kr. w. Kuby - Młyny; !8430 - na S od E kr. w. Nida.

Not.: DRYMMER 1890; BRÓż i in. 1990.

Pyrola rotundifolia - Zarośla przy torfowiskach, bory bagienne, zarośla przy torfiastym brzegu sztucznego zbiornika wodnego; ch; zagr. r.: NT. 5 stan.: !7230 - na N od w. Zakrucze, dol. Wiernej Rz.; !7232 - na NE od w. Miedzianka; !7330 - na E od E kr. w. Gałęzice; !8200 - na SW od w. Zakrucze, W brzeg zalewu Zakrucze; !8212 - na S od E kr. w. Kresy.

Not.: MASSALSKI 1962; Bróż i in. 1990.

Ranunculus cassubicus s.lato - Grądy. 3 stan.: !7333 - na E od st. kol. Słowik; !8311 - na N od W kr. w. Starochęciny; !8422 - na N od w. Łabędziów, dol. Czarnej Nidy.

Not.: BRÓż 1981a; BRóż i in. 1990.

!Ranunculus serpens subsp. nemorosus - Grądy, zbiorowiska pośrednie między grądami a świetlistymi dąbrowami, bory mieszane; zagr.: DD; zagr. r.: VU; gat. górski (ogólnogr.). 23 stan.: 7231 - na NW od osady Gajówka; 7321 - na S od W kr. w. Jaworznia; 7322 - na N od w. Janów, Podzamecka G.;

\footnotetext{
1 Spośród stanowisk wymienionych w pracy ŁAZARSKIEGO i in. (2018) w niniejszym wykazie przedstawiono tylko te, które stwierdzone były przez autora w latach 2010-2019.
} 
7323 - na N od msc. Kielce - Białogon, g. Marmurek; 7331 - na N od E kr. w. Szewce; 7332 - na N od msc. Zgórsko; 7333 - na E od st. kol. Słowik; 7430 - na N od W kr. ul. Posłowickiej, Kielce; 7431 - na S od msc. Kielce - Kawetczyzna; 8200 - na N od w. Dołki; 8201 - na W od w. Milechowy; 8202 - na N od E kr. w. Bolmin, Grząby Bolmińskie; 8213 - na N od w. Mosty, Grzywy Korzeckowskie; 8310 - na S od E kr. w. Korzecko, Grzywy Korzeckowskie; 8320 - na SE od SE kr. w. Mosty; 8323 - na SW od W kr. w. Brzeziny, Las Nidzki; 8400 - na S od ul. Na Stole, Kielce, Kowalski Las; 8401 - na SW od msc. Postole; 8402 - na S od W kr. w. Suków - Babie, N zbocze Babiej G.; 8410 - na S od E kr. w. Kowala Duża; 8411 - na N od w. Bilcza - Podgórze, Kowalski Las; 8412 - na S od W kr. w. Suków - Babie, S zbocze Babiej G.; 8422 - na NW od W kr. w. Kuby - Młyny.

Rosa gallica - Ciepłolubne zarośla i okrajki; CH; zagr.: VU; VU; zagr. r.: VU. 5 stan.: wykaz stanowisk w pracy ŁAZARSKI 2016a.

Not.: MASSALSKI 1962; BRÓŻ 1986.

! Rosa jundzilli - Ciepłolubne zarośla; zagr. r.: EN. 4 stan.: 8202 - na N od kościoła we w. Bolmin; 8202 - na N od E kr. w. Bolmin; 8322 - na W od S kr. w. Lipowica; 8422 - na E od w. Bieleckie Młyny.

Rubus bifrons - Lasy liściaste, bory mieszane, zarośla ciepłolubne; zagr. r.: NT. 5 stan.: !7231 - na NW od prz. Gajówka; !8200 - na N od w. Dołki, g. Brogowica; !8211 - na N od w. Bocheniec, W zbocze Bocheńskiej G.; !8310 - na NE od E kr. w. Mosty; !8402 - na S od E kr. msc. Kielce - Dyminy.

Not.: MASSALSKI 1962; BRÓż i in. 1990; ZIELIŃSKI 2004.

Rubus crispomarginatus - Lasy liściaste, ciepłolubne zarośla; zagr. r.: NT. 8 stan.: !7321 - na S od w. Stanisławów, g. Plebańska; !7322 - na N od E kr. w. Jaworznia, g. Kopaczowa; 7431 - na SW od msc. Kielce - Podlesie; 7432 - na W od msc. Kielce - Bukówka; 8213 - na N od W kr. w. Mosty; na E od w. Jedlnica; !8402 - na S od W kr. w. Suków - Babie, Babia G.; !8412 - na N od w. Bilcza - Zastawie, S zbocze Babiej G.; !8413 - na S od E kr. w. Suków - Babie.

Not.: ZIELIŃSKI 2004.

! Rubus glivicensis - Lasy liściaste, bory mieszane; zagr. r.: EN. 2 stan.: 8201 - na $\mathrm{N}$ od w. Bocheniec, Bocheńska G.; 8202 - na N od w. Jedlnica.

! Rubus kuleszae - Lasy liściaste, bory mieszane i ich skraje; zagr. r.: VU. 6 stan.: 7221 - na E od w. Wesoła, Wesołowska G.; 7231 - na NW od w. Milechowy, Milechowska G.; 7323 - na N od msc. Kielce - Białogon, W zbocze g. Bruszni; 8200 - na N od w. Dołki, g. Brogowica; 8201 - na W od cmentarza we w. Bolmin, g. Wrzosówka; 8213 - na E od w. Jedlnica.

! Rubus radula - Bór sosnowy; zagr. r.: EN. 1 stan.: 8201 - na W od cmentarza we w. Bolmin, g. Wrzosówka.

! Rubus schnedleri - Bór mieszany; zagr. r.: EN. 1 stan.: 8323 - na NW od w. Nida, Las Nidzki, G. Jatkowa.

Rubus sulcatus - Lasy liściaste, bory mieszane; zagr. r.: NT. 4 stan.: !8213 - na N od W kr. w. Mosty; !8310 - na S od w. Korzecko; !8412 - na E od w. Bilcza - Podgórze; !8413 - na S od E kr. w. Suków - Babie.

Not.: MASSALSKI 1962.

Senecio ovatus - Buczyny, jedliny, bory mieszane, ziołorośla w dolinach strumieni; zagr. r.: VU; gat. górski (regl.). 8 stan.: !7330 - na NW od w. Zelejowa; !7331 - na S od E kr. w. Zawada; 7333 - na E od st. kol. Słowik; 7430 - na N od W kr. ul. Posłowickiej, Kielce; !7431 - na N od ul. Leśniówka, Kielce; 7432 - na S od msc. Kielce - Pod Telegrafem; !8401 - na SE od ul. Na Stole, Kielce, Las Kowalski; 8402 - na NE od E kr. msc. Kielce - Dyminy.

Not.: Drymmer 1890; Bróż \& PRZEMYSKI 1981; Bróż i in. 1990.

! Senecio rivularis - Zarośla wierzbowe przy torfowisku przejściowym; zagr. r.: VU; gat. górski (ogólnogr.). 1 stan.: 7222 - na W od ul. Słonecznej we w. Bławatków. 
Stellaria longifolia - Bory bagienne; zagr. r.: NT. 2 stan.: !8412 - na NE od osady Podsukowie; !8413 - na S od E kr. w. Suków-Babie.

Not.: BRóż i in. 1990.

Stellaria nemorum - Grądy, łęgi, brzegi strumieni. 7 stan.: !7322 - na S od E kr. w. Jaworznia; 7332 - na NW od msc. Zgórsko; 7333 - na E od st. kol. Słowik; 7430 - na N od W kr. ul. Posłowickiej, Kielce; !7433 - Mójcza; !8323 - na S od W kr. w. Brzeziny; !8403 - na E od w. Suków, dol. Lubrzanki.

Not.: DRYMMER 1890; BRÓŻ i in. 1990.

! Taxus baccata - Jeden osobnik w borze mieszanym; ch; zagr. r.: VU. 1 stan.: 8422 - na NW od W kr. w. Kuby - Młyny.

Thalictrum aquilegiifolium - Grądy; zagr. r.: LC. 19 stan.: !7222 - na N od w. Lesica; !7223 - na S od W kr. w. Rykoszyn; !7230 - na NE od w. Zakrucze; !7233 - na NW od E kr. w. Skiby; !7323 - Kielce - Białogon, g. Brusznia; 7333 - na NE od st. kol. Słowik; 7431 - na S od msc. Kielce - Kawetczyzna; 7432 - na S od msc. Kielce - Pod Telegrafem; !8201 - na W od w. Milechowy; !8203 - Polichno; 8211 - na N od wsi Bocheniec; !8212 - na NW od wsi Choiny, Wzg. Wilkomijskie; !8213 - na S od w. Korzecko - Zarośle, Grzywy Korzeckowskie; !8223 - na S od w. Mosty, g. Bzowica; 8302 - Bolechowice; N zbocze Czerwonej G.; !8310 - na S od E kr. w. Korzecko, Grzywy Korzeckowskie; !8323 - na SW od W kr. w. Brzeziny, Las Nidzki; !8401 - na S od ul. Leśniówka, Kielce, Kowalski Las; !8402 - na S od W kr. w. Suków - Babie, N zbocze Babiej G.

Not.: DRYMMER 1890; BRÓż i in. 1990.

Trifolium rubens - Świetliste dąbrowy, ciepłolubne zarośla i okrajki; zagr.: VU; zagr. r.: VU. 25 stan.: !7221 - na E od w. Wesoła, Wesołowska G.; !7223 - na N od W kr. w. Rykoszyn; 7230 - na E od w. Zakrucze; 7232 - Miedzianka, g. Miedzianka; !7312 - Szczukowice; !7322 - na N od w. Janów, Podzamecka G.; 7323 - na N od msc. Kielce - Białogon, G. Stokowa; !7332 - na NW od msc. Zgórsko; 8200 - na N od w. Dołki; !8203 - Polichno; 8211 - na N od wsi Bocheniec; 8212 - na S od w. Bolmin, Wzg. Wilkomijskie; 8213 - na S od w. Korzecko - Zarośle, Grzywy Korzeckowskie; !8223 - na S od w. Mosty, g. Bzowica; !8300 - na NW od msc. Chęciny, g. Sosnówka; 8302 - na NE od w. Bolechowice, g. Berberysówka; !8303 - na S od w. Nowiny, gm. Sitkówka - Nowiny; 8310 - na S od E kr. w. Korzecko, Grzywy Korzeckowskie; 8311 - na N od E kr. w. Starochęciny, g. Zaklikowa; !8312 - na S od w. Radkowice; !8313 - na S od W kr. w. Kowala Duża; !8322 - na W od w. Lipowica, Grabówki; 8401 - na S od ul. Leśniówka, Kielce, Kowalski Las; !8411 - na N i S od w. Bilcza - Podgórze; 8412 - na S od W kr. w. Suków - Babie, S zbocze Babiej G.

Not.: Massalski 1962; Bróż \& Durczak 1978; Bróż \& PrZemyski 1981; Wnuk 1986; Bróż 1988; BRÓż i in. 1990.

Vaccinium uliginosum - Bory bagienne, obrzeża torfowisk. 7 stan.: !7222 - na NE od E kr. w. Lesica; na NW od w. Skałka; 7223 - na N od w. Skałka; 77230 - na N od w. Zakrucze; !8401 - na S od W kr. msc. Kielce - Dyminy; !8411 - na NE od w. Bilcza - Podgórze; !8412 - na N od w. Bilcza - Zastawie; !8413 - na NW od NW kr. w. Marzysz, dol. Lubrzanki.

Not.: DRYMMER 1890.

Valeriana sambucifolia - Łęgi i zarośla łęgowe w dolinach rzek i strumieni. Gat. górski (ogólnogr.). 21 stan.: !7223 - na S od W kr. w. Rykoszyn; !7230 - na NE od w. Zakrucze, dol. Wiernej Rz.; !7233 - na N od w. Polichno; 7332 - na NE od msc. Czerwona G., dol. Bobrzyczki; 7333 - na E od st. kol. Słowik; 7430 - na N od W kr. ul. Posłowickiej, Kielce; !7433 - Mójcza, dol. Lubrzanki; !8200 - na NE od w. Dołki, dol. Wiernej Rz.; !8202 - na N od w. Jedlnica, dol. Hutki; !8203 - na NE od w. Polichno; !8211 - na E od w. Bocheniec; !8212 - na S od w. Jedlnica; !8302 - na E od msc. Czerwona G., dol. Bobrzyczki; !8313 - na S od SE kr. w. Wola Murowana; !8321 - na NE od w. Tokarnia; !8322 - na E od w. Lipowica; !8412 - na N od w. Bilcza - Zastawie; !8413 - na E od S kr. w. Suków - Modrzewie, dol. Lubrzanki; !8422 - na SE od w. Bilcza - Zastawie; 8423 - na W od NW kr. w. Marzysz - Kiełków, dol. Czarnej Nidy; !8431 - na E od SE kr. w. Brzeziny.

Not.: BRóż \& PrZEMYSKI 1981; BRóż i in. 1990. 
Veratrum lobelianum - Wąwozy w grądach, łęgi, zbocza dolin strumieni; ch; zagr. r.: VU; gat. górski (ogólnogr.). 11 stan.: !7222 - na N od w. Lesica; !7233 - na NW od W kr. w. Skiby; !7322 - na S od E kr. w. Jaworznia; 77330 - na E od E kr. w. Gałęzice; 7331 - na S od E kr. w. Zawada; na N od E kr. w. Szewce; 7332 - na NW od msc. Zgórsko; !7333 - na E od st. kol. Słowik; 7430 - na N od W kr. ul. Posłowickiej, Kielce; 7431 - na S od msc. Kielce - Kawetczyzna; !8212 - na E od ujścia Wiernej Rz., Wzg. Wilkomijskie (ŁAZARSKI 2011); 8213 - na N od w. Mosty, Grzywy Korzeckowskie; 8310 - na E od w. Korzecko, Grzywy Korzeckowskie.

Not.: BRÓż 1981a; BRÓż \& PrZEMYsKI 1987, 1988; BRÓż i in. 1990.

Veronica montana - Brzegi strumieni, wilgotne pobocza dróg w cienistych lasach liściastych; zagr. r.: VU; gat. górski (regl.). 6 stan.: !7322 - na S od E kr. w. Jaworznia; !7330 - na SW od w. Zawada; 7332 - na NE od msc. Zgórsko; 7333 - na N od E kr. w. Zagrody; na E od st. kol. Słowik; !7430 - na N od W kr. ul. Posłowickiej, Kielce; !7431 - na S od msc. Kielce - Kawetczyzna.

Not.: P. Posłowickie, g. Biesak, leg. Bróż \& Molendowski 1985 (KTC); P. Zgórskie, uroczysko Ławy, leg. Molendowska \& Bróż 1985 (KTC); P. Zgórskie, g. Patrol, leg. Bróż \& Molendowska 1986 (KTC); BRÓż i in. 1990.

Vicia dumetorum - Dąbrowy, jedliny, zarośla na zrębach; zagr.: NT; zagr. r.: VU. 3 stan.: 7332 - na NW od msc. Zgórsko; !7333 - na E od st. kol. Słowik; 7430 - na N od W kr. ul. Posłowickiej, Kielce.

Not.: BRóż i in. 1990.

Vicia pisiformis - Świetliste dąbrowy, zarośla ciepłolubne; zagr.: EN; zagr. r.: EN. 19 stan.: !7221 - na E od w. Wesoła, N zbocze Wesołowskiej G.; !7230 - na E od w. Zakrucze; 7231 - na W od osady Gajówka; !7232 - Miedzianka, g. Miedzianka; !7233 - na N od w. Polichno, g. Hutka; !7320 - na SW od W kr. w. Łaziska k. Piekoszowa; !7322 - na N od w. Janów, Podzamecka G.; !7330 - na NW od w. Skiby, g. Stokówka; na N od w. Skiby, G. Wsiowa; 7332 - na NW od msc. Zgórsko; 7333 - na E od st. kol. Słowik; 7430 - na N od W kr. ul. Posłowickiej, Kielce; 7432 - na NW od W kr. w. Suków - Borki; 8201 - na N od w. Milechowy; !8202 - na N od E kr. w. Bolmin, Grząby Bolmińskie; 8203 - na S od w. Polichno; 8213 - na S od w. Korzecko - Zarośle, Grzywy Korzeckowskie; 8302 - na NE od w. Bolechowice, g. Berberysówka; !8323 - na S od W kr. w. Brzeziny; !8420 - na S od centr. cz. w. Brzeziny.

Not.: Drymmer 1890; MasSALSKi 1962; Bróż \& DuRCZAK 1978; Bróż 1981b; Bróż i in. 1990.

\section{DYSKUSJA}

Lista obejmuje 106 gatunków stwierdzonych w zbiorowiskach leśnych i zaroślowych południowo-zachodniej części Gór Świętokrzyskich. Wśród zamieszczonych gatunków 25 jest nowych dla badanego terenu. Wykaz zawiera 43 gatunki chronione w Polsce (RozPorzaDZENIE 2014), z których większość jest objętych ochroną częściową. W siedliskach, których dotyczy opracowanie, stwierdzono 82 gatunki zagrożone: 37 gatunków zagrożonych w kraju (KAŹMIERCZAKOwa i in. 2014, 2016) oraz 75 gatunków zagrożonych regionalnie (BRóż \& PRZEMYSKI 2009). Wśród 92 gatunków chronionych i zagrożonych przeważają rzadkie oraz bardzo rzadkie (Tab. 1, Ryc. 2).

W grupie roślin zagrożonych w kraju dominują gatunki bliskie zagrożenia (kategoria NT) i narażone (kategoria VU). Niektóre z nich są gatunkami częstymi w południowo-zachodniej części Gór Świętokrzyskich, jak np.: Cephalanthera damasonium, Cimicifuga europaea, Trifolium rubens, a nawet bardzo częstymi lub dość pospolitym, np. Chimaphila umbellata, czy Platanthera chlorantha. Gatunki z kategorii EN (zagrożone wyginięciem), tj.: Festuca amethystina subsp. ritschlii, Inula hirta, Pulsatilla patens subsp. patens, $P$. vernalis, występują na nielicznych stanowiskach, a tylko Vicia pisiformis jest gatunkiem 
częstym. W zbiorowiskach leśnych i zaroślowych stwierdzono jeden gatunek krytycznie zagrożony w kraju (kategoria CR) - Adenophora liliifolia. W niniejszym wykazie rośliny z ,czerwonej listy” Wyżyny Małopolskiej reprezentowane są głównie przez gatunki narażone na wyginięcie (kategoria VU). Wysoki udział mają także gatunki bliskie zagrożenia (kategoria NT) oraz zagrożone wyginięciem (kategoria EN). Regionalnie krytycznie zagrożone gatunki występują zwykle na nielicznych stanowiskach, są to m.in. Barbarea stricta, Hierochloë odorata (Tab. 1, Ryc. 3).

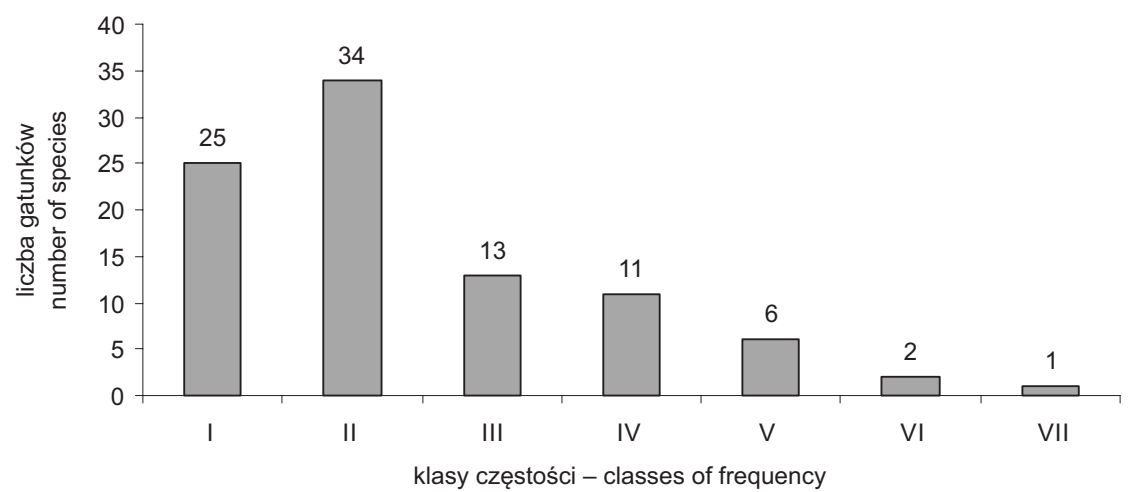

Ryc. 2. Udział gatunków chronionych oraz zagrożonych ze zbiorowisk leśnych i zaroślowych we florze południowo-zachodniej części Gór Świętokrzyskich w wyznaczonych klasach częstości (w nawiasach podano liczby stanowisk): I - bardzo rzadko (1-3), II - rzadko (4-9), III - niezbyt często (10-18), IV - często (19-27), V - bardzo często (28-36), VI - dość pospolicie (37-45), VII - pospolicie (46-54)

Fig. 2. Shares of endangered and protected species among forest and shrubland species in the south-western part of the Świętokrzyskie Mountains, by frequency class (number of localities given in parentheses): I - very rare (1-3), II - rare (4-9), III - infrequent (10-18), IV - frequent (19-27), V - very frequent (28-36), VI - rather common (37-45), VII - common (46-54)

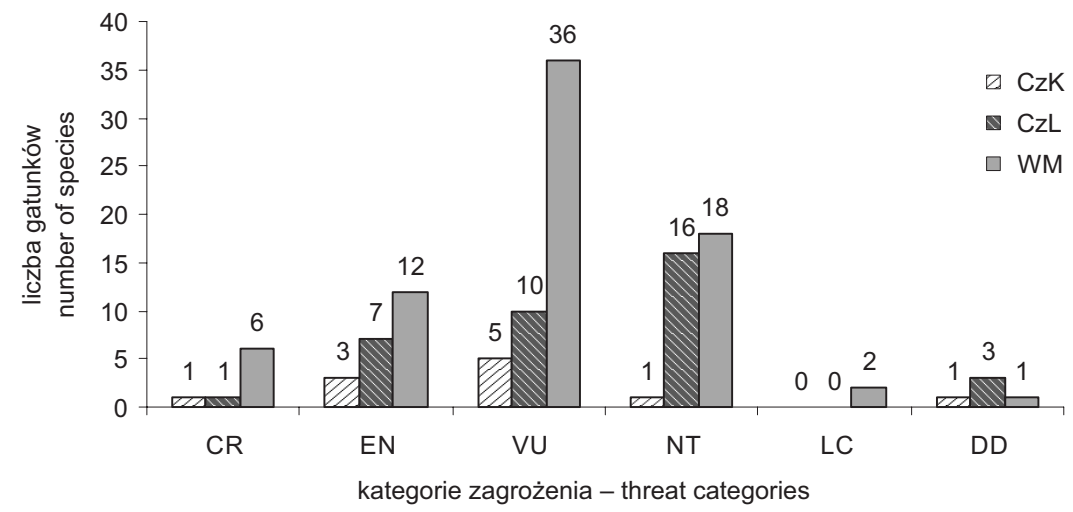

Ryc. 3. Liczbowy udział gatunków z Polskiej czerwonej księgi roślin (CzK), „,czerwonej listy” Polski (CzL) oraz „,czerwonej listy” Wyżyny Małopolskiej (WM) wśród gatunków muraw oraz ciepłolubnych okrajków w południowozachodniej części Gór Świętokrzyskich w poszczególnych kategoriach zagrożenia

Fig. 3. Numerical shares and threat categories of species from the Polish Red Data Book of Plants (CzK), the red list of Poland (CzL) and the red list of the Małopolska Upland (WM) among forest and shrubland species in the south-western part of the Świętokrzyskie Mountains 
Tabela 1. Gatunki zagrożone oraz chronione stwierdzone w zbiorowiskach leśnych i zaroślowych Wzgórz Chęcińskich i Pasma Dymińskiego: CzK - Polska czerwona księga roślin (KAźMIERCZAKowa i in. 2014), CzL - polska czerwona lista (KAŹMIERCZAKOwa et al. 2016), WM - czerwona lista Wyżyny Małopolskiej (BRóż \& PrZEMYSKi 2009), CH - gatunki objęte ochroną ścisłą; ch - gatunki objęte ochroną częściową (RoZPORZĄDZENIE 2014). Po nazwie gatunkowej podano w nawiasie liczbę stanowisk

Table 1. Red-listed and protected species recorded in forest and shrub communities of the Chęciny Hills and Dyminy Range: CzK - Polish red data book of plants (KAźMIERCZAKowa et al. 2014), CzL - Polish red list (KAŹMIERCZAKOwA et al. 2016), WM - red list of Małopolska Upland (BRóż \& PRZEMYSKI 2009), CH - strictly protected species; ch - partially protected species (ROZPORZĄDZENIE 2014). Number of localities is given in parentheses after the species name

\begin{tabular}{|c|c|c|c|c|}
\hline \multirow{2}{*}{$\begin{array}{l}\text { Nazwa gatunku (liczba stanowisk) } \\
\text { [Name of species (number of localities)] }\end{array}$} & \multicolumn{3}{|c|}{$\begin{array}{l}\text { Kategorie zagrożenia } \\
\text { (Threat categories) }\end{array}$} & \multirow{2}{*}{$\begin{array}{l}\text { Ochrona prawna } \\
\text { (Legal protection } \\
\text { of species) }\end{array}$} \\
\hline & $\mathrm{CzK}$ & $\mathrm{CzL}$ & WM & \\
\hline Aconitum variegatum subsp. variegatum (14) & - & - & VU & $\mathrm{ch}$ \\
\hline Adenophora liliifolia (4) & $\mathrm{CR}$ & $\mathrm{CR}$ & $\mathrm{EN}$ & $\mathrm{CH}$ \\
\hline Allium ursinum subsp. ucrainicum (2) & - & - & NT & $\mathrm{ch}$ \\
\hline Anemone ranunculoides (9) & - & - & LC & - \\
\hline Antennaria dioica $(2)$ & - & NT & NT & - \\
\hline Anthriscus nitida (2) & - & - & VU & - \\
\hline Aquilegia vulgaris (29) & - & - & - & $\mathrm{ch}$ \\
\hline Arctostaphylos uva-ursi (1) & - & NT & NT & $\mathrm{CH}$ \\
\hline Aruncus sylvestris (10) & - & - & NT & $\mathrm{ch}$ \\
\hline Astragalus arenarius (18) & - & NT & - & - \\
\hline Avenula planiculmis var. hispidula (6) & VU & VU & VU & - \\
\hline Barbarea stricta $(4)$ & - & - & $\mathrm{CR}$ & - \\
\hline Bromus benekenii (5) & - & - & $\mathrm{VU}$ & - \\
\hline Bupleurum longifolium (7) & - & EN & VU & $\mathrm{CH}$ \\
\hline Campanula cervicaria (2) & DD & DD & - & - \\
\hline Cardamine flexuosa (3) & - & - & VU & - \\
\hline Cardamine impatiens (3) & - & - & VU & - \\
\hline Carex pallidula (12) & NT & NT & $\mathrm{CR}$ & - \\
\hline Cephalanthera damasonium (23) & - & NT & VU & $\mathrm{CH}$ \\
\hline Cephalanthera longifolia (11) & - & VU & VU & $\mathrm{CH}$ \\
\hline Cephalanthera rubra (6) & $\mathrm{VU}$ & VU & EN & $\mathrm{CH}$ \\
\hline Cerasus fruticosa (14) & $\mathrm{VU}$ & VU & VU & $\mathrm{ch}$ \\
\hline Chimaphila umbellata (35) & - & NT & NT & $\mathrm{ch}$ \\
\hline Cimicifuga europaea (22) & - & NT & NT & $\mathrm{ch}$ \\
\hline Corallorhiza trifida (6) & - & VU & EN & $\mathrm{CH}$ \\
\hline Corydalis cava (2) & - & - & VU & - \\
\hline Corydalis solida (8) & - & - & NT & - \\
\hline Cotoneaster integerrimus (19) & - & - & NT & - \\
\hline Cotoneaster niger (1) & - & - & VU & - \\
\hline Dactylis polygama (5) & - & - & EN & - \\
\hline Dactylorhiza fuchsii (3) & - & - & EN & $\mathrm{CH}$ \\
\hline Daphne mezereum (36) & - & - & - & $\mathrm{ch}$ \\
\hline Dentaria enneaphyllos (4) & - & - & VU & - \\
\hline Digitalis grandiflora (23) & - & - & NT & $\mathrm{ch}$ \\
\hline Dryopteris cristata (4) & - & - & VU & - \\
\hline Epipactis helleborine (50) & - & - & - & $\mathrm{ch}$ \\
\hline Epipactis atrorubens (10) & - & NT & VU & $\mathrm{ch}$ \\
\hline
\end{tabular}


Tabela 1. Kontynuacja - Table 1. Continued

\begin{tabular}{|c|c|c|c|c|}
\hline \multirow{2}{*}{$\begin{array}{l}\text { Nazwa gatunku (liczba stanowisk) } \\
\text { [Name of species (number of localities)] }\end{array}$} & \multicolumn{3}{|c|}{$\begin{array}{l}\text { Kategorie zagrożenia } \\
\text { (Threat categories) }\end{array}$} & \multirow{2}{*}{$\begin{array}{l}\text { Ochrona prawna } \\
\text { (Legal protection } \\
\text { of species) }\end{array}$} \\
\hline & $\mathrm{CzK}$ & $\mathrm{CzL}$ & WM & \\
\hline Euphorbia amygdaloides (30) & - & - & NT & - \\
\hline Festuca amethystina subsp. ritschlii (6) & EN & EN & $\mathrm{VU}$ & $\mathrm{CH}$ \\
\hline Galanthus nivalis (1) & - & - & $\mathrm{VU}$ & $\mathrm{ch}$ \\
\hline Galium rotundifolium (4) & - & NT & $\mathrm{EN}$ & - \\
\hline Geranium sylvaticum (11) & - & NT & $\mathrm{VU}$ & - \\
\hline Glechoma hirsuta (1) & - & - & DD & - \\
\hline Goodyera repens (10) & - & NT & $\mathrm{VU}$ & $\mathrm{CH}$ \\
\hline Hierochloë odorata (2) & - & $\mathrm{VU}$ & $\mathrm{CR}$ & $\mathrm{ch}$ \\
\hline Hypochoeris maculata (6) & - & - & $\mathrm{VU}$ & - \\
\hline Inula conyza (2) & - & - & $\mathrm{EN}$ & - \\
\hline Inula hirta (1) & - & EN & $\mathrm{VU}$ & - \\
\hline Inula salicina $(13)$ & - & - & NT & - \\
\hline Laserpitium prutenicum (1) & - & VU & $\mathrm{VU}$ & - \\
\hline Lathyrus pisiformis (9) & VU & EN & CR & $\mathrm{CH}$ \\
\hline Ledum palustre $(8)$ & - & - & - & $\mathrm{ch}$ \\
\hline Lilium martagon (40) & - & - & - & $\mathrm{CH}$ \\
\hline Lycopodium annotinum (7) & - & NT & - & $\mathrm{ch}$ \\
\hline Lycopodium clavatum (4) & - & NT & - & $\mathrm{ch}$ \\
\hline Matteucia struthiopteris (5) & - & - & VU & $\mathrm{ch}$ \\
\hline Melandrium rubrum (1) & - & - & NT & - \\
\hline Melittis melissophyllum (35) & - & - & - & $\mathrm{CH}$ \\
\hline Moneses uniflora (19) & - & NT & - & $\mathrm{ch}$ \\
\hline Monotropa hypophegea (5) & - & $\mathrm{DD}$ & - & - \\
\hline Neottia nidus-avis (27) & - & - & - & $\mathrm{ch}$ \\
\hline Polygala amara subsp. brachyptera (8) & - & - & $\mathrm{VU}$ & - \\
\hline Polygonatum verticillatum (16) & - & - & NT & - \\
\hline Polystichum aculeatum (8) & - & - & $\mathrm{VU}$ & $\mathrm{CH}$ \\
\hline Platanthera bifolia (6) & - & - & - & $\mathrm{ch}$ \\
\hline Platanthera chlorantha (37) & - & NT & - & $\mathrm{ch}$ \\
\hline Pulmonaria angustifolia (12) & - & VU & $\mathrm{VU}$ & - \\
\hline Pulsatilla patens subsp. patens (6) & EN & EN & $\mathrm{CR}$ & $\mathrm{CH}$ \\
\hline Pulsatilla vernalis (1) & EN & EN & $\mathrm{CR}$ & $\mathrm{CH}$ \\
\hline Pyrola chlorantha (27) & - & - & - & $\mathrm{ch}$ \\
\hline Pyrola minor (28) & - & - & - & $\mathrm{ch}$ \\
\hline Pyrola rotundifolia (5) & - & - & NT & $\mathrm{ch}$ \\
\hline Ranunculus serpens subsp. nemorosus (23) & - & DD & VU & - \\
\hline Rosa gallica (5) & VU & VU & $\mathrm{VU}$ & $\mathrm{CH}$ \\
\hline Rosa jundzilli (4) & - & - & $\mathrm{EN}$ & - \\
\hline Rubus bifrons (5) & - & - & NT & - \\
\hline Rubus crispomarginatus (8) & - & - & NT & - \\
\hline Rubus glivicensis (2) & - & - & EN & - \\
\hline Rubus kuleszae (6) & - & - & $\mathrm{VU}$ & - \\
\hline Rubus radula (1) & - & - & $\mathrm{EN}$ & - \\
\hline Rubus schnedleri (1) & - & - & $\mathrm{EN}$ & - \\
\hline
\end{tabular}


Tabela 1. Kontynuacja - Table 1. Continued

\begin{tabular}{l|c|c|c|c}
\hline \hline \multirow{2}{*}{$\begin{array}{l}\text { Nazwa gatunku (liczba stanowisk) } \\
\text { [Name of species (number of localities)] }\end{array}$} & \multicolumn{3}{|c|}{$\begin{array}{c}\text { Kategorie zagrożenia } \\
\text { (Threat categories) }\end{array}$} & $\begin{array}{c}\text { Ochrona prawna } \\
\text { (Legal protection } \\
\text { of species) }\end{array}$ \\
\cline { 2 - 5 } & CzK & CzL & WM & - \\
Rubus sulcatus (4) & - & - & NT & - \\
Senecio ovatus (8) & - & - & VU & - \\
Senecio rivularis (1) & - & - & VU & - \\
Stellaria longifolia (2) & - & - & NT & - \\
Taxus baccata (1) & - & - & VU & - \\
Thalictrum aquilegiifolium (19) & - & - & LC & - \\
Trifolium rubens (25) & - & VU & VU & - \\
Veratrum lobelianum (11) & - & - & VU & ch \\
Veronica montana (6) & - & - & VU & - \\
Vicia dumetorum (3) & - & NT & VU & - \\
Vicia pisiformis (19) & - & EN & EN & - \\
\hline
\end{tabular}

Poza gatunkami chronionymi i zagrożonymi w wykazie ujęto także 6 gatunków bardzo rzadkich lub rzadkich w południowo-zachodniej części Gór Świętokrzyskich, tj. posiadających tutaj do 9 stanowisk.

Obecność niektórych gatunków leśnych i zaroślowych wyróżnia florę południowo-zachodniej części Gór Świętokrzyskich na tle innych regionów Wyżyny Małopolskiej lub kraju. Są wśród nich taksony występujące w świetlistych dąbrowach, np.: Adenophora liliifolia, Avenula planiculmis var. hispidula, Inula conyza, Lathyrus pisiformis, grądach i buczynach - Bupleurum longifolium, Dentaria enneaphyllos, Corallorhiza trifida, w świeżych borach sosnowych - Polygala amara subsp. brachyptera, Pulsatilla patens subsp. patens, $P$. vernalis, w jedlinach - Galium rotundifolium oraz w zaroślach ciepłolubnych - Cerasus fruticosa, Cotoneaster integerrimus, C. niger, Rosa gallica (ZAJĄC \& ZAJĄC 2001).

Na szczególną uwagę zasługuje Lathyrus pisiformis, którego większość aktualnych stanowisk w Polsce położona jest w badanej części Gór Świętokrzyskich (z koncentracją na Wzgórzach Chęcińskich - HerBICH \& ŁAZARSKI 2014). Na wyjątkowo częste występowanie w tym regionie Wyżyny Małopolskiej Avenula planiculmis, zwrócili uwagę BRóż i PrZEMYSKI (1983-1985b). Południowo-zachodnia część Gór Świętokrzyskich to także jeden z nielicznych obszarów w południowej Polsce, gdzie znajdują się aktualne stanowiska dwóch wymierających sasanek - Pulsatilla patens subsp. patens i $P$. vernalis (ŁAZARSKI i in. 2018).

Zwraca uwagę znaczący udział gatunków z rodzaju Rubus. Niektóre z nich posiadają w tej części Gór Świętokrzyskich jedne z niewielu stanowisk na Wyżynie Małopolskiej (Rubus glivicensis, $R$. bifrons), a inne, jak $R$. crispomarginatus i $R$. kuleszae, koncentruja tutaj swoje stanowiska (ZIELIŃSKI 2004).

Góry Świętokrzyskie to jeden z obszarów na niżu polskim o najwyższej koncentracji gatunków górskich (ZAJĄc 1996). W zbiorowiskach leśnych i zaroślowych Wzgórz Chęcińskich i Pasma Dymińskiego odnaleziono 22 gatunki reprezentujące element górski (przeważają wśród nich gatunki ogólnogórskie i reglowe). 
Niektóre z przedstawionych gatunków na terenie badań osiągają granice swoich zasięgów lub zbliżają się tutaj do nich. Są to przede wszystkim: Bupleurum longifolium, Cerasus fruticosa, Inula conyza, Polygala amara subsp. brachyptera (na granicy północnej), Senecio rivularis, Pulsatilla vernalis, Festuca amethystina subsp. ritschlii (na granicy wschodniej), Lathyrus pisiformis (na granicy zachodniej) (ZAJĄC \& ZAJĄC 2001).

Wiele spośród wymienionych gatunków rzadkich i zagrożonych jest szczególnie wrażliwych na zmiany warunków siedliskowych, jakie zachodzą w zbiorowiskach leśnych po zaprzestaniu tradycyjnego ich użytkowania. Działalność człowieka, polegająca przede wszystkim na wypasie zwierząt, wygrabianiu ściółki i zbiorze mchu, przez stulecia kształtowała zbiorowiska leśne. Pozbawione czynników hamujących podlegają one procesom regeneracji. W ich wyniku wzrasta zwarcie poszczególnych warstw lasu, a zwłaszcza warstwy krzewów, co prowadzi do wzrostu zacienienia warstwy runa i w konsekwencji ustępowania zielnych gatunków światłożądnych i ciepłolubnych. Najsilniej zagrożone są gatunki półnaturalnych zbiorowisk leśnych, za które uważane są świetliste dąbrowy (JAKUBOWSKA-GABARA 1993; JAKUBOWSKA-GABARA 2004). Poważnym zagrożeniem dla lasów liściastych i związanych z nimi cennych przyrodniczo gatunków, jest również niewłaściwie prowadzona gospodarka leśna. W minionych dziesięcioleciach na siedliskach świetlistych dąbrów i grądów na wapiennych wzniesieniach Wzgórz Chęcińskich powszechnie wysadzano gatunki iglaste (głównie sosnę i jodłę) oraz buka. Tak prowadzona gospodarka leśna doprowadziła do dewastacji dużych powierzchni świetlistych dąbrów i grądów (m.in. na Grzywach Korzeckowskich, wzniesieniach w pobliżu Bocheńca oraz w Paśmie Kadzielniańskim) oraz eliminacji wielu stanowisk rzadkich ciepłolubnych gatunków (BRóż 1990). Niestety wciąż, chociaż w mniejszej skali, na siedliskach świetlistych dąbrów i grądów wysadzane są sosny, jodły i buki.

W celu zachowania cennych przyrodniczo gatunków leśnych i zaroślowych konieczne są m.in. zabiegi ochrony czynnej, które odpowiadałyby tradycyjnym formom użytkowania lasów i zarośli. Należy również rozważyć przynajmniej częściowe usunięcie (przerzedzenie) wysadzonych buków, sosen i jodeł na siedliskach świetlistych dąbrów i grądów, aby zmniejszyć ich negatywne oddziaływanie na siedlisko (JAKUBOwSKA-GABARA 2004; ANDRZEJEWSKI i in. 2015; ŁAZARSKI 2017; ŁAZARSKI i in. 2018). Postulowane od dawna projekty objęcia ochroną rezerwatową lesistych wzniesienień Wzgórz Chęcińskich o największych walorach przyrodniczych (w tym przede wszystkim Grzyw Korzeckowskich) nie zostały zrealizowane (BRóż 1986).

Spośród ciepłolubnych zarośli z klasy Rhamno-Prunetea tylko zbiorowiska z wiśnią karłowatą są zagrożone na skutek ekspansji innych, większych gatunków krzewiastych (głównie śliwy tarniny). Ponadto, wiśni karłowatej budującej zbiorowisko potencjalnie zagraża hybrydyzacja ze spokrewnioną wiśnią pospolitą (WóJCICKI 2014). Zbiorowiska z wiśnią karłowatą należy objąć monitoringiem przyrodniczym. W płatach, w których wzrastałby udział śliwy tarniny i innych ekspansywnych krzewów należałoby wprowadzić regularną ich wycinkę (PERZANOWSKA i in. 2015).

Najbardziej zagrożone gatunki leśne na badanym terenie wymagają zabezpieczenia w warunkach ex situ. Są wśród nich przede wszystkim: Adenophora liliifolia, Pulsatilla patens subsp. patens, $P$. vernalis (gatunki na izolowanych stanowiskach, zagrożone w Polsce 
i Europie - KAŹMIERCZAKOWA i in. 2014, 2016) oraz Inula conyza (będąca na izolowanym stanowisku na północnej granicy zasięgu).

Podziękowania. Serdecznie dziękuję za oznaczenie lub rewizję okazów zielnikowych: Pani dr Kai Roli (Allium ursinum subsp. ucrainicum, Senecio ovatus), Panu prof. dr. Jerzemu Zielińskiemu oraz Panu dr. hab. Krzysztofowi Oklejewiczowi (rodzaj Rosa, Rubus). Serdecznie dziękuję również Panu Józefowi Gajdzie za udostępnienie mapy z położeniem terenu badań w sieci ATPOL.

Wyniki badań, zrealizowane w ramach tematu badawczego $\mathrm{nr} 342 / 13 / \mathrm{S}$, zostały sfinansowane z dotacji na naukę, przyznanej przez Ministerstwo Nauki i Szkolnictwa Wyższego.

\section{LITERATURA}

ANDRZEJEwSKI H., KIEDRZYŃSKi M. \& JAKUBOwSKA-GABARA J. 2015. Czynna ochrona dąbrowy świetlistej Potentillo albae-Quercetum w rezerwacie Napoleonów (Polska Środkowa) - rezultaty jednorazowego zabiegu. - Studia i Materiały Centrum Edukacji Przyrodniczo-Leśnej 17(42/1): 125-131.

BŁoŃSKI F. 1892. Przyczynek do flory jawnokwiatowej oraz skrytokwiatowej naczyniowej kilkunastu okolic kraju. - Pamiętnik Fizjograficzny 12: 131-149.

Browicz K. \& GostyŃsKa M. 1963a. Cotoneaster integerrmia Med. - W: S. BiAŁoboK \& Z. CZYBiński (red.), Atlas rozmieszczenia drzew i krzewów w Polsce. Zeszyt 1: 15-16 + mapa 102. Państwowe Wydawnictwo Naukowe, Poznań.

Browicz K. \& GostyńsKa M. 1963b. Cotoneaster melanocarpa Lodd. - W: S. BiAŁoboK \& Z. CZYBiński (red.), Atlas rozmieszczenia drzew i krzewów w Polsce. Zeszyt 1: 11-12 + mapa 100. Państwowe Wydawnictwo Naukowe, Warszawa - Poznań.

Browicz K. \& Gostyńska M. 1964. Cerasus fruticosa Woronow. - W: S. BiaŁoboK \& Z. CZYBiński (red.), Atlas rozmieszczenia drzew i krzewów w Polsce. Zeszyt 3: 12-14 + mapa 121. Państwowe Wydawnictwo Naukowe, Warszawa - Poznań.

Browicz K. \& KaczmareK Cz. 1972. Arctostaphylos uva-ursi L. - W: K. Browicz (red.), Atlas rozmieszczenia drzew i krzewów w Polsce. Zeszyt 11: 23-28 + mapa 156. Państwowe Wydawnictwo Naukowe, Warszawa - Poznań.

BRÓż E. 1977. Notatki florystyczne z Gór Świętokrzyskich. Część I. - Fragmenta Floristica et Geobotanica 23(3-4): 295-300.

BRÓż E. 1981a. Notatki florystyczne z Gór Świętokrzyskich. Część II. - Fragmenta Floristica et Geobotanica 27(3): 321-330.

BRóż E. 1981b. Notatki florystyczne z Gór Świętokrzyskich. Część III. - Fragmenta Floristica et Geobotanica 27(4): 607-617.

BRÓż E. 1986. Projektowany rezerwat leśny Grzywy Korzeckowskie w Górach Świętokrzyskich. - Chrońmy Przyrodę Ojczystą 42(1): 23-37.

BRóż E. 1988. Walory geobotaniczne wybranych rezerwatów przyrody nieożywionej w Górach Świętokrzyskich oraz problemy ich ochrony. - Chrońmy Przyrodę Ojczystą 44(2): 18-34.

BRÓż E. 1990. Zagrożenia rodzimej flory naczyniowej Krainy Świętokrzyskiej: stan obecny, przyczyny oraz tendencje i prognozy. - Chrońmy Przyrodę Ojczystą 46(2-3): 14-31.

BRÓż E. \& DurCZAK K. 1978. Interesujące oraz rzadkie gatunki roślin naczyniowych z zachodniej części Pasma Kadzielniańskiego w Górach Świętokrzyskich. - Studia Kieleckie 18(2): 7-16.

BRÓż E. \& MACIEJCZAK B. 1991. Niektóre nowe oraz rzadkie i zagrożone gatunki roślin naczyniowych we florze miasta i strefy podmiejskiej Kielc. - Fragmenta Floristica et Geobotanica 36(1): 171-179. 
BRóż E. \& Przemyski A. 1981. Chronione oraz rzadsze elementy flory naczyniowej Krainy Świętokrzyskiej. - Studia Kieleckie 32(4): 141-160.

BRÓż E. \& PRZEMYSKI A. 1983-1985a. Nowe stanowiska rzadkich gatunków roślin naczyniowych z lasów Wyżyny Środkowomałopolskiej. - Fragmenta Floristica et Geobotanica 29(1): 19-30.

Bróż E. \& Przemyski A. 1983-1985b. Występowanie Helictotrichon planiculme (Schrad.) Pilg. na polskim niżu. - Fragmenta Floristica et Geobotanica 29(1): 31-38.

BRÓż E. \& PrZEMYSKI A. 1987. Chronione oraz rzadsze elementy flory naczyniowej Krainy Świętokrzyskiej (część II). - Studia Kieleckie 56(4): 7-18.

BRóż E. \& PRZEMYski A. 1988. Nowe stanowiska rzadkich oraz zagrożonych gatunków roślin naczyniowych na Wyżynie Środkowomałopolskiej i jej pobrzeżach. - Fragmenta Floristica et Geobotanica 33(3-4): 239-249.

BRóż E. \& PRZEMYSKi A. 1989. Nowe stanowiska rzadkich gatunków roślin naczyniowych z lasów Wyżyny Środkowomałopolskiej. Część II. - Fragmenta Floristica et Geobotanica 34(1-2): 15-25.

Bróż E. \& Przemyski A. 2009. The red list of vascular plants in the Wyżyna Małopolska Upland (S Poland). - W: Z. MireK \& A. Nikel (red.), Rare, relict and endangered plants and fungi in Poland, s. 123-136. W. Szafer Institute of Botany, Polish Academy of Sciences, Kraków.

Bróż E., Maciejczak B., Molendowska D. \& Molendowski T. 1990. Rośliny naczyniowe Pasm Posłowickiego, Dymińskiego i Zgórskiego w Górach Świętokrzyskich (na obszarze miasta oraz strefy podmiejskiej kielc). - Studia Kieleckie 67-68(3-4): 43-79.

CioseK M. T. \& BzDon G. 2000. Stanowiska wybranych gatunków z rodziny storczykowatych z okolic Kielc i Pińczowa. - Chrońmy Przyrodę Ojczystą 56(4): 76-79.

CZubIŃsKa M. 1962. Rozmieszczenie Galium rotundifolium L. na Nizinie Wielkopolsko-Kujawskiej. - Badania Fizjograficzne nad Polską Zachodnią 10: 275-289.

DRYMMER K. 1890. Rośliny najbliższych okolic Kielc. - Pamiętnik Fizjograficzny 10: 47-74.

FREY L. 1991. Taxonomy, karyology and distribution of selected genera of tribe Aveneae (Poaceae) in Poland: I. Avenula. - Fragmenta Floristica et Geobotanica 35(1-2): 101-137.

Frey L., Pięroś-Mirkowa H., Podgórska M. \& Łazarski G. 2014. VU Avenula planiculmis (Schrad.) W. Sauer \& Chmelitschek Owsica spłaszczona. - W: R. KAŹMIERCZAKowA, K. ZARZYCKI \& Z. MiReK (red.), Polska czerwona księga roślin. Paprotniki i rośliny naczyniowe. Wyd. 3, s. 641-643. Instytut Ochrony Przyrody PAN, Kraków.

GŁAZEK T. 1976a. Roślinność rezerwatu geologicznego „Góra Zelejowa” koło Chęcin. - Chrońmy Przyrodę Ojczystą 32(3): 57-62.

GŁAZEK T. 1976b. Niektóre rzadsze gatunki roślin naczyniowych wzgórz wapiennych Okręgu Chęcińskiego. - Fragmenta Floristica et Geobotanica 22(3): 291-293.

GŁAZEK T. 1987. Murawy i zarośla kserotermiczne wzgórz wapiennych Okręgu Chęcińskiego. s. 40. Kieleckie Towarzystwo Naukowe, Wydawnictwo Geologiczne, Warszawa.

GrZYl A. \& Ronikier M. 2011. Pulsatilla vernalis (Ranunculaceae) in the Polish lowlands: current population resources of a declining species. - Polish Botanical Journal 56(2): 185-194.

Herbich J. 1988. Lathyrus pisiformis L. - Fragmenta Floristica et Geobotanica 33(3-4): 397-407.

HeRBich J. \& ŁAZARSKI G. 2014. VU Lathyrus pisiformis L. Groszek wielkoprzylistkowy. - W: R. KAźMIERCZAKowa, K. ZARZYCKi \& Z. MireK (red.), Polska czerwona księga roślin. Paprotniki i rośliny naczyniowe. Wyd. 3, s. 291-293. Instytut Ochrony Przyrody PAN, Kraków.

JAGIEŁŁO M. 1986-1987. Analysis of population variability and distribution of species from the Dactylorhiza maculata group (Orchidaceae) in Poland. - Fragmenta Floristica et Geobotanica 31-32(3-4): 333-383. 
Jakubowska-Gabara J. 1993. Recesja zespołu świetlistej dąbrowy Potentillo albae-Quercetum Libb. 1933 w Polsce. s. 190. Uniwersytet Łódzki, Łódź.

JakUbowska-Gabara J. 1994. Distribution of Festuca amethystina L. subsp. ritschlii (Hackel) Lemke ex Markgr.-Dannenb. in Poland. - Acta Societatis Botanicorum Poloniae 63(1): 87-95.

Jakubowska-Gabara J. 2004. Świetlista dąbrowa Potentillo albae-Quercetum. - W: J. Herbich (red.), Lasy i Bory. Poradniki ochrony siedlisk i gatunków Natura 2000 - podręcznik metodyczny. 5, s. 261-265. Ministerstwo Środowiska, Warszawa.

KAMIEŃSKI F. 1885. Spis paproci krajowych. - Pamiętnik fizjograficzny 5: 109-111.

KaZNOwsKi K. 1922. Przyczynek do flory okolic Zawiercia i Wyżyny Kielecko-Sandomierskiej. Kosmos 47: 101-104.

KAZNOwSKI K. 1930. Sasanki Gór Świętokrzyskich. - Ziemia 15(20): 425-429.

KaŹmierczakowa R., ZARZYCKi K. \& MireK Z. (red.). 2014. Polska czerwona księga roślin. Paprotniki i rośliny naczyniowe. Wyd. 3. s. 895. Instytut Ochrony Przyrody PAN, Kraków.

Kaźmierczakowa R., Bloch-OrŁowska J., Celka Z., Cwener A., Dajdok Z., Michalska-Hejduk D., PAWLIKowski P., SzCZEś́niak E. \& ZiARneK K. 2016. Polska czerwona lista paprotników i roślin kwiatowych. s. 44. Instytut Ochrony Przyrody Polskiej Akademii Nauk, Kraków.

KONDRACKI J. 2002. Geografia regionalna Polski. Wyd. 3. s. 441. Wydawnictwo Naukowe PWN, Warszawa.

ŁAZARSKI G. 2011. Rzadkie i zagrożone gatunki roślin naczyniowych w dolinie Białej Nidy w pobliżu Małogoszcza (centralna część Wyżyny Małopolskiej). - Fragmenta Floristica et Geobotanica Polonica 18(2): 257-264.

ŁAZARSKi G. 2012. Występowanie Avenula planiculmis (Schrad.) W. Sauer \& Chmelitschek na Wzgórzach Chęcińskich. - W: M. SzczePaniaK \& B. PASzKo (red.), X Ogólnopolskie Spotkanie Naukowe, Biologia traw. Materiały konferencji, s. 68. Instytut Botaniki im. W. Szafera Polskiej Akademii Nauk, Kraków.

ŁAZARSKI G. 2014. Lathyrus pisiformis (Fabaceae) na Wyżynie Małopolskiej (S Polska): występowanie i zagrożenia. - Fragmenta Floristica et Geobotanica Polonica 21(2): 229-239.

ŁAZARSKI G. 2016a. Rosa gallica (Rosaceae) w Górach Świętokrzyskich i na terenach przyległych (Wyżyna Małopolska) - występowanie i zagrożenia. - Fragmenta Floristica et Geobotanica Polonica 23(1): 3-11.

ŁAZARSKI G. 2016b. Festuca amethystina (Poaceae) - nowy gatunek dla flory Płaskowyżu Jędrzejowskiego. - Fragmenta Floristica et Geobotanica Polonica 23(2): 370-374.

ŁAZARSKI G. 2017. Adenophora liliifolia w Górach Świętokrzyskich - zmiany w rozmieszczeniu, zasoby populacyjne, zagrożenia. - Fragmenta Floristica et Geobotanica Polonica 24(1): 183-188.

ŁAZARSKI G. 2019. Chronione, rzadkie i zagrożone gatunki roślin naczyniowych we florze Wzgórz Chęcińskich i Pasma Dymińskiego (Wyżyna Małopolska) - cz. I. Gatunki muraw oraz ciepłolubnych okrajków. - Fragmenta Floristica et Geobotanica Polonica 26(1): 49-73.

ŁAZARSKI G. 2020. Expansion of cold-adapted orchid Goodyera repens (Orchidaceae) in times of global warming - report from southern Poland. - Polish Journal of Ecology 68(4): 313-322. https://doi.org/ 10.3161/15052249PJE2020.68.4.004

ŁAZARSKI G. \& PodgóRSKA M. 2020. Nowe, silnie zagrożone stanowisko Pulsatilla patens subsp. patens (Ranunculaceae) w Górach Świętokrzyskich (Wyżyna Małopolska). - Fragmenta Floristica et Geobotanica Polonica 27(2): 527-535.

ŁaZARSKi G., Nobis M. \& KozaK M. 2014. NT Carex pallidula Harmaja Turzyca bladozielona. - W: R. KAźMiercZaKowa, K. ZARZYCKI \& Z. MireK (red.), Polska czerwona księga roślin. Paprotniki i rośliny naczyniowe. Wyd. 3, 713-715. Instytut Ochrony Przyrody PAN, Kraków. 
Łazarski G., Podgórska M. \& Bróż E. 2018. Sasanki ostoi Wzgórza Chęcińsko-Kieleckie i jej pobrzeży - rozmieszczenie, stan zachowania i perspektywy ochrony. - Chrońmy Przyrodę Ojczystą 74(1): 37-51.

MASSALSKi E. 1962. Obrazy roślinności Krainy Gór Świętokrzyskich. s. 120. Wydawnictwo ArtystycznoGraficzne, Kraków.

MatuszKiewicz W. 2008. Przewodnik do oznaczania zbiorowisk roślinnych Polski. Vademecum Geobotanicum 3. s. 537. Wydawnictwo Naukowe PWN, Warszawa.

MAZuR M. 1975. Wstępne doniesienie o florze i roślinności rezerwatu Góra Zelejowa pod Chęcinami. - Studia Kieleckie 8(4): 86-89.

Mirek Z., Piękoś-Mirkowa H., Zając A. \& Zając M. 2002. Vascular plants of Poland. A checklist. - W: Z. MireK (red.), Biodiversity of Poland. 1, s. 442. W. Szafer Institute of Botany, Polish Academy of Sciences, Kraków.

PawŁowski B. 1958. Krytyczne uwagi o polskich formach rodzaju Polygala L. - Fragmenta Floristica et Geobotanica 3(2): 35-68.

PerzanowsKa J., Świerkosz K. \& ReCZyŃska K. 2015. Subkontynentalne zarośla okołopannońskie. - W: W. Mróz (red.), Monitoring siedlisk przyrodniczych. Przewodnik metodyczny. Część IV, s. 153-166. GIOŚ, Warszawa.

Podsiedlik M. \& BedNorz L. 2012. Aktualny stan populacji Avenula planiculmis var. hispidula (Poaceae) w mezoregionie Gór Świętokrzyskich. - Fragmenta Floristica et Geobotanica Polonica 19(2): 421-426.

Przemyski A. \& Piwowarski B. 2011. Buławnik czerwony Cephalanthera rubra (Orchidaceae) na Wyżynie Małopolskiej. - Chrońmy Przyrodę Ojczystą 67(3): 232-243.

PRZEMYSKI A. \& SOlON J. 2010. Charakterystyka typologiczna i przegląd zbiorowisk roślinnych. - W: A. ŚwIERcz (red.), Monografia Chęcińsko-Kieleckiego Parku Krajobrazowego, s. 144-169. Uniwersytet Humanistyczno-Przyrodniczy Jana Kochanowskiego w Kielcach, Kieleckie Towarzystwo Naukowe, Kielce.

Rola K. 2012. Taxonomy and distribution of Allium ursinum (Liliaceae) in Poland and adjacent countries. - Biologia 67(6): 1080-1087.

RosTAFIŃSKI J. 1886. Krytyczne zestawienie paprotników Królestwa Polskiego. - Pamiętnik Fizjograficzny 6: $235-250$.

ROZPORZĄDZENIE 2014. Rozporządzenie Ministra Środowiska z dnia 9 października 2014 r. w sprawie ochrony gatunkowej roślin. Dz. U. 2014, poz. 1409.

SzCZecińsKa M., ŁaZARSKI G., BiLSKA K. \& SAWICKI J. 2017. The complete plastid genome and nuclear genome markers provide the molecular evidence for the hybrid origin of Pulsatilla $\times$ hackelii Pohl. - Turkish Journal of Botany 41(4): 329-337.

Wnuk Z. 1986. Sasanki Pulsatilla Mill. sp. w Bocheńcu koło Małogoszczy w województwie kieleckim. - Chrońmy Przyrodę Ojczystą 42(6): 65-67.

WóJCiCKI J. J. 2014. VU Cerasus fruticosa Pallas Wiśnia karłowata (wisienka stepowa). - W: R. KAźMierCZAKOWA, K. ZARZYCKI \& Z. MireK (red.), Polska czerwona księga roślin. Paprotniki i rośliny naczyniowe. Wyd. 3, 274-276. Instytut Ochrony Przyrody PAN, Kraków.

ZAJĄC A. 1978. Założenia metodyczne „Atlasu rozmieszczenia roślin naczyniowych w Polsce”. - Wiadomości Botaniczne 22(3): 145-155.

ZAJĄC A. \& ZAJĄC M. (red.) 2001. Atlas rozmieszczenia roślin naczyniowych w Polsce. s. xii + 714. Nakładem Pracowni Chorologii Komputerowej Instytutu Botaniki Uniwersytetu Jagiellońskiego, Kraków.

ZaJąC M. 1996. Mountain Vascular Plants in the Polish Lowlands. - Polish Botanical Studies 11: 1-92.

Zieliński J. 2004. The genus Rubus (Rosaceae) in Poland. - Polish Botanical Studies 16: 1-300. 


\section{SUMMARY}

The Chęciny Hills and the Dyminy Range occupy the south-western part of the Świętokrzyskie Mountains (S Poland, Fig. 1; KondRACKI 2002). The characteristics of the study area, along with its topographic map, are included in the first part of the study (EAZARSKI 2019). The second part of the paper presents the localities of protected, rare and red-listed species that have been recorded in forest and shrub communities.

The research was carried out in 2010-2015 and supplemented in 2016-2019, using the cartogram method (ZAJĄC 1978; ŁAZARSKI 2019). The paper presents the localities of 106 species recorded in forest and shrub communities. Among them are 43 species protected in Poland (RozPORZADZZENIE 2014), 37 species red-listed in Poland (KAŹMIERCZAKowa et al. 2014, 2016) and 75 species from the red list of the Małopolska Upland (Bróź \& PrZEMYsKi 2009; Fig. 3, Tab. 1).

Some of the forest and shrubland species are specific elements of the flora of the south-western part of the Świętokrzyskie Mountains. Among them are taxa found in thermophilous oakwoods (e.g. Adenophora liliifolia, Avenula planiculmis var. hispidula, Inula conyza, Lathyrus pisiformis), oak-hornbeam and beech forest (Bupleurum longifolium, Dentaria enneaphyllos, Corallorhiza trifida), pine forest (Polygala amara subsp. brachyptera, Pulsatilla patens subsp. patens, P. vernalis), fir forest (Galium rotundifolium) and thermophilous shrub communities (Cerasus fruticosa, Cotoneaster integerrimus, C. niger, Rosa gallica). Particularly noteworthy is Lathyrus pisiformis: the majority of its current localities in Poland are in the studied part of the Świętokrzyskie Mountains (HERBICH \& ŁAZARSKI 2014). Avenula planiculmis is another species whose localities are concentrated in the study area (BRÓź \& PRZEMYSKI 1983-1985b). The southwestern part of the Świętokrzyskie Mountains is also one of the few areas in southern Poland where two declining pasque flower species occur (Pulsatilla patens subsp. patens, P. vernalis) (ŁAZARSKI et al. 2018). The significant share of Rubus species in the studied flora is noteworthy. In this part of the Świętokrzyskie Mountains some brambles have one of their few localities in the Małopolska Upland (Rubus glivicensis, $R$. bifrons), while others such as $R$. crispomarginatus and $R$. kulszae have their localities concentrated here (ZIELIŃSKI 2004). The Świętokrzyskie Mountains are one of the Polish lowland areas where the highest concentration of mountain plants has been found (ZAJAcC 1996). Twenty-two mountain species were recorded in forest and shrub communities.

Some of the listed species reach or approach their range limit in the study area: Inula conyza, Polygala amara subsp. brachyptera (at the northern limit), Senecio rivularis, Pulsatilla vernalis, Festuca amethystina subsp. ritschlii (at the eastern limit) and Lathyrus pisiformis (at the western limit).

To preserve the most threatened forest and shrubland species, active conservation is necessary, which should involve the restoration of traditional uses of forest and shrub communities. Forestry management measures appropriate to the particular habitat are also required.

Wptynęto: 27.12.2019 r.; przyjęto do druku: 01.10.2020 r. 